\title{
A Panax-centric view of invasive species and a case study on the effects of garlic mustard (Alliaria petiolata)
}

\author{
Kerry Lynn Wixted \\ West Virginia University
}

Follow this and additional works at: https://researchrepository.wvu.edu/etd

\section{Recommended Citation}

Wixted, Kerry Lynn, "A Panax-centric view of invasive species and a case study on the effects of garlic mustard (Alliaria petiolata)" (2009). Graduate Theses, Dissertations, and Problem Reports. 2906.

https://researchrepository.wvu.edu/etd/2906

This Thesis is protected by copyright and/or related rights. It has been brought to you by the The Research Repository @ WVU with permission from the rights-holder(s). You are free to use this Thesis in any way that is permitted by the copyright and related rights legislation that applies to your use. For other uses you must obtain permission from the rights-holder(s) directly, unless additional rights are indicated by a Creative Commons license in the record and/ or on the work itself. This Thesis has been accepted for inclusion in WVU Graduate Theses, Dissertations, and Problem Reports collection by an authorized administrator of The Research Repository @ WVU. For more information, please contact researchrepository@mail.wvu.edu. 
A Panax-centric view of invasive species and a case study on the effects of garlic mustard (Alliaria petiolata)

\author{
Kerry Lynn Wixted \\ Dissertation submitted to \\ Eberly College of Arts and Sciences \\ at West Virginia University \\ in partial fulfillment of the requirements \\ for the degree of \\ Master of Science \\ James B. McGraw, Ph.D., Chair \\ Richard Thomas, Ph.D. \\ Cynthia Huebner, Ph.D. \\ Department of Biology \\ Morgantown, West Virginia \\ 2009
}




\begin{abstract}
A Panax-centric view of invasive species and the competitive and allelopathic effects of garlic mustard (Alliaria petiolata) on American ginseng (Panax quinquefolius L.)
\end{abstract}

\title{
Kerry Lynn Wixted
}

American ginseng (Panax quinquefolius L.) is a long-lived, valuable herb found throughout the eastern United States. Habitat degradation, harvest pressures, overbrowsing by deer and reduced genetic diversity are believed to be the primary causes of decline for this rare species; however the widespread threat of invasive species has yet to be investigated. Therefore, my research focused on examining the level of exposure of individuals and populations of ginseng to invasive plant species as well as partitioning the effects of a particular invasive, garlic mustard (Alliaria petiolata), into those owing to competition and allelopathy. For my first study, I used a novel plant-centric sampling approach to investigate the level of invasion in 30 natural ginseng populations. I found a high level of invasion both among populations and near individual ginseng plants. I also found a higher probability of previously harvested populations and larger populations to contain invasive species. My second study addressed the competitive and allelopathic effects of garlic mustard on ginseng seedlings. I found that while there was no competitive effect of garlic mustard, there was a tendency for garlic mustard to allelopathically increase mortality in ginseng seedlings. The third study examined how garlic mustard density and leaf litter addition may affect ginseng growth and reproduction. While the extreme garlic mustard treatments showed no significant effect on ginseng growth, increased weight of garlic mustard leaf litter had a tendency to decrease the proportion of flower buds which developed into berries and seeds. The overall conclusions from these studies are that invasive species are prevalent within natural ginseng populations, and ginseng recruitment within garlic mustard invaded populations may be reduced.

Keywords: American ginseng, invasive species, garlic mustard, Panax quinquefolius, Alliaria petiolata 


\section{ACKNOWLEDGMENTS}

Although I would like to think that weathering and writing the entirety of my thesis makes me an island, it takes a lot more than just one person to accomplish such a task. :- As the old African proverb says, "It takes a village to raise a child" or a grad student, in my case. With that being said, first and foremost, I would like to thank my adviser, Dr. Jim McGraw, for his guidance, dedication and support throughout my master's career. Jim encouraged me to explore my own research interests which really fostered creativity in my experiments. His excitement and ingenuity always helped me through difficulties experienced with research. In addition, my committee members Dr. Richard Thomas and Dr. Cynthia Huebner were very helpful with providing feedback on my initial research plans as well as with thesis revisions.

I also would like to thank the numerous people who have helped with field and lab work. Undergraduates such as Adam Martin, Clare Maloy, Mark Guido, Allison Kenyon and Jackie Boczyuk helped out in the field and made work fun. Dr. Ann Lubbers and Len DiIoia also helped with the invasive survey. Bob Beyfuss also contributed ginseng seeds. Jerry Baird, despite his hatred of hills, would spend several days hiking plants or cages up and down them to help out while torturing me with earthworms in the process. David Kazyak also spent quite a bit of time helping me dig in that awfully rocky soil at the research forest. Chris Huffman gave great advice and helped with soil testing. Pat Lutsie and Wendy Sites were always there to lend equipment and to mediate between me and the printer. I also would like to thank the varying forms of fungi which attacked my ginseng seeds and roots and created additional hurdles. I learned how to quickly address unforeseen problems and still got the job done despite your hyphal inhibitions!

My labmates, both past and present, have been a great influence. Emily Mooney provided great advice and hilarious observations. Alyssa Hanna has been a great friend, always there to cheer me up and help out with her expertise. Sara Souther has been a joy to work with, and I will always remember Zach Bradford's dedication to ginseng research, even while sleeping.

In addition, I would like to thank the many professors at Frostburg State University who helped me to get into graduate school. Dr. Linda Lyon took me under her wing and had me become involved in numerous undergraduate research and community projects. In addition, Dr. Ron Barry allowed me to become a more effective scientific writer. Dr. Frank Ammer also was a great friend and mentor throughout my later years in undergrad. My friends such as Jeremy Smith, Heather Robertson, Angie Burns, Sarah Millman and Diana Moore were always there for me and cheered me on at every step of this journey.

I cannot forget to thank my family in all of this, especially my father who let me know I had po-tential early on. Both of my parents also helped instill my love of nature at an early stage. Ms. Sarah has also been a second mom throughout the years.

Last but not least, I have to give thanks to the furry ones who were always there for me. My fat guinea pigs provided much entertainment as well as Tobie and Willow. Sunshine was always happy to see me, and frequently put her furry paw down to let me know when it was time to stop working by laying on my papers or computer.

Also, funding for this research was provided by the NSF grant DEB-0613611 awarded to J.B. McGraw. 


\section{TABLE OF CONTENTS}

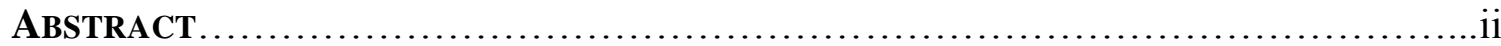

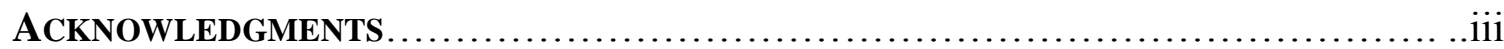

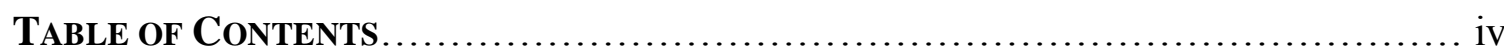

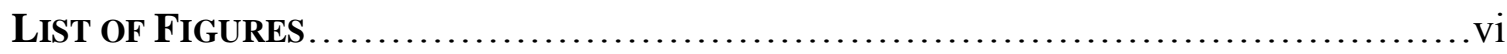

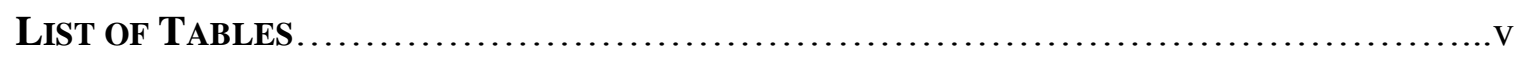

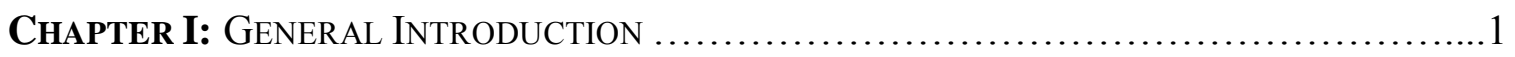

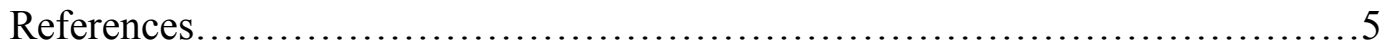

ChAPTER II: A PANAX-CENTRIC VIEW OF INVASIVE SPECIES...........................

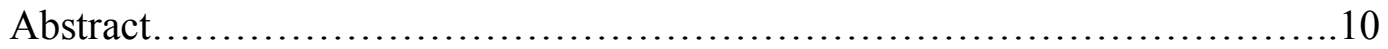

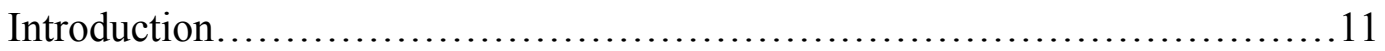

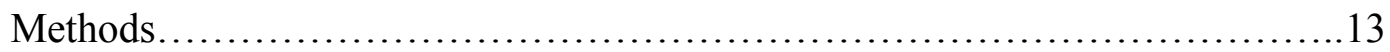

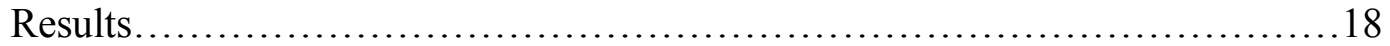

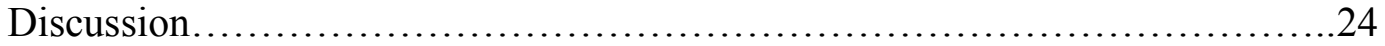

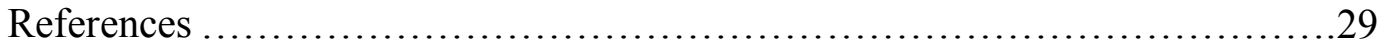

ChAPTER III: COMPETITIVE AND ALLELOPATHIC EFFECTS OF GARLIC MUSTARD (ALLIARIA

PETIOLATA) ON AMERICAN GINSENG (PANAX QUINQUEFOLIUS L.)...........................34

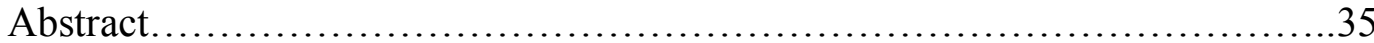

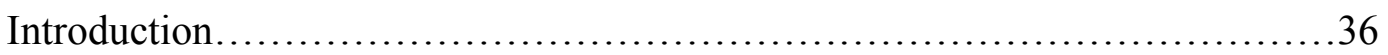

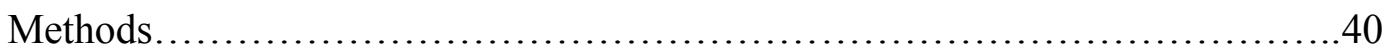

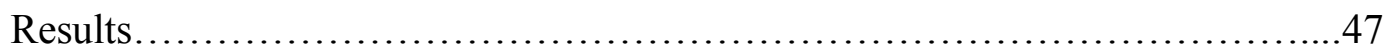

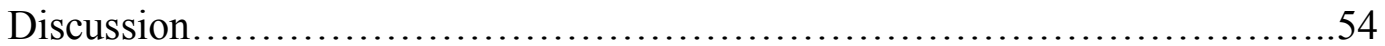

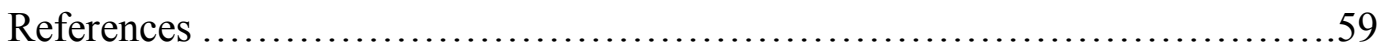

ChAPTER IV: EFFeCtS Of GARLIC MUSTARD (ALLIARIA PETIOLATA) DENSITY AND LEAF LITTER ADDITION ON AMERICAN GINSENG (PANAX QUINQUEFOLIUS L.) GROWTH AND

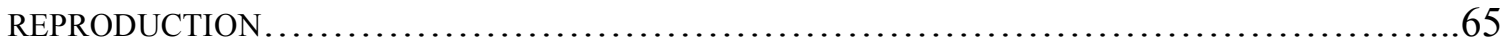

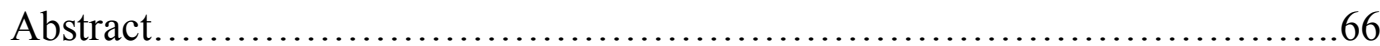

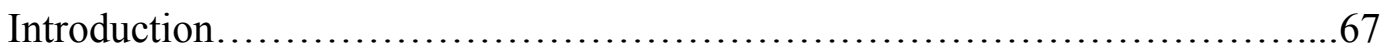

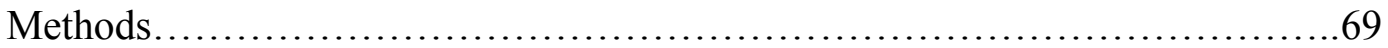

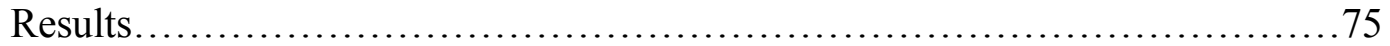

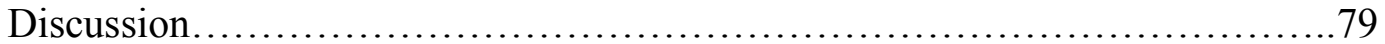

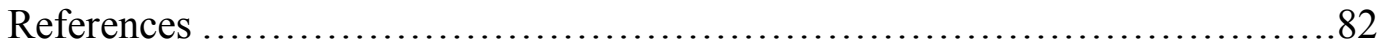

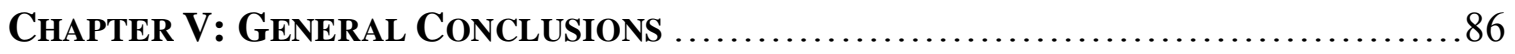

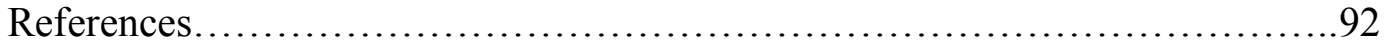

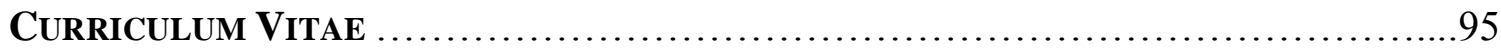




\section{LIST OF FigURES}

Figure 2.1: Distribution of invaded and uninvaded study populations spread over 7 states in 2007

Figure 2.2: Percentage of individual ginseng plants having a particular invasive within competitive range for $2006(\mathrm{~N}=4,540)$ and $2007(\mathrm{~N}=4,279)$...

Figure 2.3: Percentage of individuals within ginseng size classes having invasives in competitive range in 2006.

Figure 2.4: Percentage of individuals within ginseng size classes having invasives in competitive range in 2007.

Figure 3.1: Three two-way factorial permutations of the six treatments examining a) differential effects of violet presence with and without activated carbon (AC), b) differential effects of garlic mustard presence with and without $\mathrm{AC}$, and c) differential effects of the native striped violet and the invasive garlic mustard as a function of AC treatment. ...

Figure 3.2: (a) Effect of striped violet presence on ginseng seedling mortality in 2007 and (b) differential effect of garlic mustard on ginseng seedling mortality (2007) depending on AC treatment after two growing seasons.

Figure 3.3 Differential effect of striped violet on mean shoot length $(\mathrm{cm})$ depended on AC treatment.

Figure 3.4: (a) Differential effect of competitor species on mean shoot length $(\mathrm{cm})$ in ginseng seedlings after two growing seasons depending on AC treatment; means with the same letter are not significantly different using the Tukey-Kramer HSD a posteriori test, and (b) effect of activated carbon presence and competitor identity on mean shoot mass in ginseng seedlings after two growing seasons $(0.05<\mathrm{p}<0.10)$; no post hoc test was performed since the interactive effect was only a trend.

Figure 3.5: (a) Competitor biomass after two growing seasons and (b) effect of AC treatment on biomass of the competitor after two growing seasons.

Figure 4.1: (a) One-way regression showing relationship between mean berries/flower bud for ginseng and initial mass of garlic mustard leaf litter and (b) relationship between mean seeds/flower bud. 


\section{LIST OF TABLES}

Table 2.1: Attributes of study populations ..................................... 16

Table 2.2: Proportion of ginseng individuals with invasive plant within competitive range in each population in 2006 and 2007.

Table 3.1: ANOVA summary table; significant values $(\mathrm{p}<0.05)$ are bolded while italicized values depict a trend $(0.05<\mathrm{p}<0.10)$. All dependent variables except the relative growth rate of leaf area were $\log$ transformed........................................48

Table 3.2: Summary table of backtransformed least-squared means and $95 \%$ confidence limits for ginseng dependent variables with a significant AC effect....

Table 4.1: ANOVA summary table of block effects for growth variables and reproductive variables for the density study; significant values $(\mathrm{p}<0.05)$ are bolded while italicized values depict a trend $(0.05<\mathrm{p}<0.10) .{ }^{1}$ denotes a $\log$ transformed variable.....76 Table 4.2: ANOVA summary table of block effects for growth variables and reproductive variables for the leaf litter addition study; significant values $(\mathrm{p}<0.05)$ are bolded while italicized values depict a trend $(0.05<\mathrm{p}<0.10) .{ }^{1}$ denotes a $\log$ transformed variable. 


\section{Chapter I:}

GENERAL INTRODUCTION 
Invasive species present some of the most substantial threats to biodiversity today, particularly to threatened or endangered plant species (Wilcove et al 1998; Millennium Ecosystem Assessment 2005). Recently, the estimated economic impact of invasives in the United States is $\$ 120$ billion per year (Pimentel et al. 2005); however this figure does not include values for decreased biodiversity and possible species extinctions. Invasives can suppress native species' recruitment and persistence (McCarthy 1997; Thomson 2005), as well as alter ecosystem properties (Ehrenfeld and Scott 2001) and processes (Vitousek and Walker 1989; D'Antonio and Vitousek 1992), all of which could result in a global impact (D'Antonio and Vitousek 1992). The success of invasive species has been attributed to a variety of factors such as escape from natural predators and pathogens (Wolfe 2002, Callaway and Aschehoug 2000; Mitchell and Power 2003), the use of "novel weapons" (Callaway and Ridenour 2004; Bais et al. 2003; Callaway et al. 2008), photosynthetic efficiency (Nagel and Griffen 2004), fast growth and prolific reproduction (Kolar and Lodge 2001).

While many invasive species typically invade disturbed areas (Hobbs and Huenneke 1992; Marvier et al. 2004; Stolgren et al. 1999), some invasive plants are able to infiltrate undisturbed forests (Ehrenfeld 1997; Knapp and Canham 2000; Nuzzo 1999; Weber and Gibson 2007). In addition, one study examining community invasibility (Levine and D'Antonio 1999) found that few communities will remain uninvaded with invasive propagule pressure. The findings from that study presents a need to quantify exposure of native species within interior forests to invasive plants as well as to understand potential negative interactions between invaders and native species. 
One major invader of deciduous forests is garlic mustard (Alliaria petiolata). Garlic mustard is a Eurasian biennial currently found in 36 states and southern Canada (Nuzzo 2000; Welk et al. 2002; USDA 2008). Garlic mustard has been found to invade habitats such as disturbed forest edges, floodplains, undisturbed understories and old growth forests (Nuzzo 1993; Nuzzo 1999; Stinson et al. 2006; Weber and Gibson 2007). Removal of garlic mustard in established plots has been found to increase abundance and diversity of native species, suggesting that it suppresses them (McCarthy 1997; Stinson et al. 2007). Furthermore, native tree seedlings grown in soils previously invaded by garlic mustard show significantly reduced growth compared to those in uninvaded soils (Stinson et al. 2006). The mechanisms underlying garlic mustard's success are thought to be resource competition and allelopathy; however species have been found to vary in their response to garlic mustard (Meekins and McCarthy 1999; Vaughn and Berhow 1999; Roberts and Anderson 2001; Prati and Bossdorf 2004; Stinson et al. 2006; Callaway et al. 2008; Rodgers et al. 2008).

In contrast, American ginseng (Panax quinquefolius L.) is a culturally and economically important native understory species found in the interior of eastern deciduous forests in North America (Bailey 1999; Robbins 2000; McGraw et al. 2003). American ginseng is a slow-growing, long-lived herbaceous species (Charron and Gagnon 1991) with low seed production and relatively high seed viability and germination (Carpenter and Cottam 1982; Lewis and Zenger 1983; Charron and Gagnon 1991). Like many other native species, ginseng forms mycorrhizal associations (Seo and Anderson 1999) which helps the plant take up limiting nutrients. However, secondary compounds produced by garlic mustard have been found to inhibit fungal mutualists 
(Roberts and Anderson 2001; Stinson et al. 2006; Callaway et al. 2008), potentially making species which rely on mycorrhizal fungi more susceptible to garlic mustard.

Due to the concern over sustainability of harvest, ginseng was listed in Appendix II of CITES (Convention on International Trade in Endangered Species of Wild Fauna and Flora). However, despite regulations, there remains a need for studies of the population and conservation status of this species (Robbins 2000). A conservation assessment of American ginseng by Kauffman (2006) identified habitat degradation and loss, poor harvest practices (Van der Voort and McGraw 2006), deer browsing (McGraw and Furedi 2005) and reduced genetic variation (Cruse-Sanders and Hamrick 2004; Grubbs and Case 2004) as potential threats to ginseng. However, no studies have examined the level of exposure and potential susceptibility of ginseng populations and individuals to invasive species. Given this important gap in our knowledge of ginseng ecology, the purpose of my research was to address the following questions: (1) What is the level of exposure of ginseng populations and individuals to invasive plant species, and what factors may predict the existence of invasive species in a population? (2) Is there a competitive effect of a particular invasive (garlic mustard) on ginseng growth and reproduction, and can that effect be attributed to allelopathy or garlic mustard density? The significance of this research lies in documenting the exposure of American ginseng to invasive plants and understanding how ginseng plants at different life stages may respond to the current threat of the invasive garlic mustard. 


\section{REFERENCES}

Bailey B (1999) Social and economic impacts of wild harvested products. Ph.D. Dissertation, West Virginia University, Morgantown, WV.

Bais HP, Vepachedu R, Gilroy S, Callaway RM, Vivanco JM (2003) Allelopathy and exotic plant invasion: from molecules and genes to species interactions. Science 301(5):1377-1380.

Callaway RM, Aschehoug ET (2000) Invasive plants versus their new and old neighbors: a mechanism for exotic invasion. Science 290:521-523.

Callaway RM, Ridenour WM (2004) Novel weapons: invasive success and the evolution of increased competitive ability. Front Ecol 2(8):436-443.

Callaway RM, Cipollini D, Barto K, Thelen GC, Hallett SG, Prati D, Stinson K Klironomos J (2008) Novel weapons: Invasive plant suppresses fungal mutualists in America but not in its native Europe. Ecology 89(4):1043-1055.

Carpenter SG, Cottam G (1982) Growth and reproduction of American ginseng (Panax quinquefolius) in Wisconsin. Can J Bot 60:2692-2696.

Charron D, Gagnon D (1991) The demography of northern populations of Panax quinquefolium (American ginseng). J Ecol 79(2):431-445.

Cruse-Sanders JM, Hamrick JL (2004) Spatial and genetic structure within populations of wild American ginseng (Panax quinquefolius L. Araliaceae). J Hered 95(4):309-321.

Ehrenfeld JG (1997) Invasion of deciduous forest preserves in the New York metropolitan region by Japanese barberry (Berberis thunbergii DC.). J Torrey Bot Soc 124:210-215.

Ehrenfeld JG, Scott NS (2001) Invasive species and the soil: effects on organisms and ecosystem processes. Ecol Appl 11(5): 1259-1260.

Grubbs HJ, Case MA (2004) Allozyme variation in American ginseng (Panax quinquefolius $\mathrm{L}$.): variation, breeding system, and implications for the current conservation practice. Conserv Genet 5:13-23.

Hobbs RJ, Huenneke LF (1992) Disturbance, diversity, and invasion: implications for conservation. Conserv Biol 6(3): 324-337.

Kaufmann G (2006) Conservation assessment for American ginseng (Panax quinquefolius) L. Eastern Research Station, USDA Forest Service, 74 pp. 
Knapp LB, Canham CD (2000) Invasion of an old-growth forest in New York by Ailanthus altissima: sapling growth and recruitment in canopy gaps. J Torrey Bot Soc 127: 307-315

Kolar CS, Lodge DM (2001) Progress in invasion biology: predicting invaders. Trends Ecol Evol 16(4):199-204.

Levine JM, D’Antonio CM (1999) Elton revisited: a review of evidence linking diversity and invisibility. Oikos $87(15-26)$

Lewis WH, Zenger VE (1982) Population dynamics of the American ginseng Panax quinquefolium (Araliaceae). Am J Bot 69:1483-1490.

Marvier M, Karieva P, Neubert MG (2004) Habitat destruction, fragmentation, and disturbance promote invasion by habitat generalists in a multispecies metapopulation. Risk Analysis 24(4): 869-878.

McCarthy B (1997) Response of a forest understory community to experimental removal of an invasive nonindigenous plant (Alliaria petiolata, Brassicaceae). In: Luken JO, Thieret JW (eds). Assessment and management of plant invasions. Springer-Verlag. New York. pp 117-130

McGraw JB, Sers SM, Van der Voort ME (2003) Distribution and abundance of Hydrastis canadensis L. (Ranunculaceae) and Panax quinquefolius L. (Araliaceae) in the central Appalachian region. J Torrey Bot Soc 130(2):62-69.

McGraw JB, Furedi MA (2005) Deer browsing and population viability of a forest understory plant. Science 307:920-922.

Meekins JF, McCarthy BC (1999) Competitive ability of Alliaria petiolata (Garlic mustard, Brassicaceae), an invasive, nonindigenous forest herb. International J Plant Sci 160(4):743-752.

Millennium Ecosystem Assessment (2005) Ecosystems and Human Well-being: Biodiversity Synthesis. World Resources Institute, Washington, DC.

Mitchell CG, Power AG (2003) Release of invasive plants from fungal and viral pathogens. Nature 421:625-627.

Nuzzo V (1993) Distribution and spread of the invasive biennial garlic mustard (Alliaria petiolata) in North America. In: McKnight BN (ed.)

Biological pollution: the control and impact of invasive exotic species. Indiana Academy of Science, Indianapolis. pp 137-146.

Nuzzo V (1999) Invasion pattern of the herb garlic mustard (Alliaria petiolata) in high quality forests. Biol Invasions 1:169-179. 
Nuzzo V (2000) Element stewardship abstract for Alliaria petiolata Garlic mustard. Arlington (VA), Nature conservancy.

Pimentel D, Zuniga R, Morrison R (2005) Update on environmental and economic costs associated with alien-invasive species in the United States. Ecol Econ 52(273288)

Prati D, Bossdorf O (2004) Allelopathic inhibition of germination by Alliaria petiolata (Brassicaceae). Am J Bot 91(2):285-288.

Robbins CS (2000) Comparative analysis of management regimes and medicinal plant trade monitoring mechanisms for American ginseng and goldenseal. Conserv Biol 1422-1434.

Roberts KJ, Anderson RC (2001) Effect of garlic mustard [Alliaria petiolata (Beib. Cavara \& Grande)] extracts on plants and arbuscular mycorrhizal (AM) fungi. Am Midl Nat 146:146-152.

Rodgers VL, Wolfe BE, Werden LK, Finzi AC (2008) The invasive species Alliaria petiolata (garlic mustard) increases soil nutrient availability in northern hardwood-conifer forests. Oecologia 157:459-471.

Seo H, Anderson RC (1990) Effect of soil microbial and mycorrhizal associations on the productivity and photosynthetic rates of Panax quinquefolium L. Myco Soc Am Newsl 41:4.

Stinson KA, Campbell SA, Powell JR, Wolfe BE, Callaway RM, Thelen GC, Hallett SG, Prati D, Klironomos JN (2006) Invasive plant suppresses the growth of native tree seedlings by disrupting belowground mutualisms. PLoS Biology 4(5): 0727-0731.

Stinson K, Kaufman S, Durbin L, Lowenstein F (2007) Impacts of garlic mustard invasion on a forest understory community. Northeastern Naturalist 14(10):73-88.

Stolgren TJ, Schell LD, Heuvel BV (1999) How grazing and soil quality affect native and exotic plant diversity in rocky mountain grasslands. Ecol Appl 9:4564.

Thomson D (2005) Measuring the effects of invasive species on the demography of a rare endemic plant. Biol Invasions 7:615-624.

United States Department of Agriculture, Natural Resources Conservation Service (2008) The PLANTS Database (http://plants.usda.gov, 09 September 2008). National Plant Data Center, Baton Rouge, LA 70874-4490 USA 
Van der Voort ME, McGraw JB (2006) Effects of harvester behavior on population growth rate affects sustainability of ginseng trade. Biol Conserv 130(4): 505-516.

Vaughn SF, Berhow MA (1999) Allelochemicals isolated from tissues of the invasive weed garlic mustard (Alliaria petiolata). J Chem Ecol 25(11):2495-2504.

Vitousek PM, Walker LR (1989) Biological invasion by Myrica faya in Hawaii: plant demography, nitrogen fixation, and ecosystem effects. Ecol Monographs 59:247-265.

Vitousek PM, Walker LR, Whiteaker LD, Mueller-Dombois D, Watson PA (1987). Biological invasion by Myrica faya alters ecosystem development in Hawaii. Science 238(4828): 802-804.

Weber JS, Gibson KD (2007) Exotic plant species in old-growth forest in Indiana. Weed Sci 55:299-304.

Welk E, Schubert K, Hoffmann MH (2002) Present and potential distribution of invasive garlic mustard (Alliaria petiolata) in North America. Diver Distrib $8: 219-233$.

Wilcove DS, Rothstein D, Dubow J, Philips A, Losos E (1998) Quantifying threats to imperiled species in the United States. Bioscience 48(8):607-615.

Wolfe LM (2002) Why alien invaders succeed: support for the escape-from-enemy hypothesis. Am Nat 160(6):705-711. 


\section{Chapter II:}

A PANAX-CENTRIC VIEW OF INVASIVE SPECIES ${ }^{1}$

This chapter is formatted for submission to the journal Biological Invasions: submitted 4/14/08, accepted 6/05/08 and published online 6/27/08 "Wixted, K. and J.B. McGraw. 2008. A Panax-centric view of invasive species. Biological Invasions DOI 10.1007/s10530-008-9301-7.” 


\begin{abstract}
Plant-centric sampling provides a novel approach to quantifying the potential impact of invasive species on native plant species. The aim of this study was to determine the level of exposure of individuals and populations of Panax quinquefolius to invasive plant species using this approach in thirty natural ginseng populations. A high level of invasion was found with $63 \%-70 \%$ of ginseng populations containing at least one invasive species. Approximately one-third of all individuals were found in close proximity to invasive plants. The most prevalent invasive species were Rosa multiflora and Berberis thunbergii. The exposure to invasives of plants in different size classes varied among populations. Invasive species presence increased with greater ginseng population sizes and presence of harvest. The abundance of invasive plants within forest interiors near this valuable medicinal herb suggests that the economic and ecological costs of competitive interactions with native species could be high.
\end{abstract}

Key words: Invasive species, Panax quinquefolius, American ginseng 


\section{INTRODUCTION}

Invasive species are economically and biologically damaging to the ecosystems in which they have been introduced (Pimentel et al. 2005; Wilcove et al. 1998). Escape from natural predators and pathogens (Callaway and Aschehoug 2000, Mitchell and Power 2003, Wolfe 2002), "novel weapons” (Bais et al. 2003; Callaway and Ridenour 2004), photosynthetic efficiency (Nagel and Griffen 2004), fast growth and prolific reproduction are some of the attributes of successful invasive plants (Kolar and Lodge 2001). Invasive plants can even change ecosystem properties such as soil chemistry (Ehrenfeld and Scott 2001) or ecosystem development (Vitousek et al. 1987). Most invasive plant species compete with natives for limited resources and some exude allelochemicals from their roots or through foliar leaching (Dorning and Cipollini 2005; Heisey 1990; Heisey 1996; Rose et al. 1983). Removal of established, invasive plants has been shown to cause an increase in native recruitment and diversity, thus suggesting they do suppress native species (McCarthy 1997; Thompson 2005). Those findings have considerable implications for forest regeneration following an invasion.

While literature on the effects of non-native invasive species on native species is extensive, no studies have examined the importance of invasives for economically valuable, native medicinal plant species. One widespread medicinal plant is American ginseng (Panax quinquefolius). Ginseng is an herbaceous perennial found within eastern deciduous forest interiors of North America. Ginseng is a flagship species that is not only important in an economic sense but also the harvest has great social and cultural significance, particularly in Appalachia (Bailey 1999). Currently, ginseng is uncommon, rare or endangered in most of its range (USDA 2007). Due to high levels of harvest and 
declining populations, ginseng harvest is listed on Appendix II of CITES (Convention on the International Trade in Endangered Species of Wild Fauna and Flora) (Robbins 2000; USFWS 2005). Despite this listing, there is still a great need for more information on the population and conservation status of ginseng (Robbins 2000), especially since invasive species pose some of the greatest threats to rare and endangered species (Wilcove et al. 1998).

Ginseng is a long-lived, slow-growing herb (Charron and Gagnon 1991) with populations that are threatened by poor harvest practices (Van der Voort and McGraw 2006), deer browsing (McGraw and Furedi 2005) and inbreeding along with reduced genetic diversity (Cruse-Sanders and Hamrick 2004, Mooney and McGraw 2007). Similar to other understory forest species, $P$. quinquefolius forms vesicular-arbuscular mycorrhizal (VAM) associations (Seo and Anderson 1990) which allow P. quinquefolius to survive in a range of soil conditions, particularly those that are phosphorus limited (Anderson et al. 1993). Allelopathic invasive plants produce chemical constituents that have been found to inhibit mycorrhizal colonization and growth (Roberts and Anderson 2001; Rose et al. 1983; Stinson et al. 2006), and would be expected, in turn, to negatively affect species dependent on those associations.

As a widespread, long-lived and slow-growing species of forest interiors, ginseng's exposure and susceptibility to invasive species is unknown. On one hand, many invasives occupy disturbed habitats (Hobbs and Huenneke 1992; Marvier et al. 2004; Stolgren et al. 1999), which are uncharacteristic for forest herbs such as ginseng (Anderson et al. 1993). However, the diversity of habitats ginseng occupies (McGraw et al. 2003), the fact some invasive plants do penetrate undisturbed forests (Ehrenfeld 1997; 
Knapp and Canham 2000; Nuzzo 1999; Weber and Gibson 2007), and the long lifetimes of ginseng plants, suggest that the effects of invasives could be important. Furthermore, given ginseng's widespread occurrence in eastern deciduous forests (Charron and Gagnon 1991), ginseng may be exposed to invasives at rates similar to other understory herbs. A study by Anderson et al. (1993) in Illinois found some of the most common herbs within ginseng populations included Smilacina racemosa, Arisaema triphyllum, Sanicula marilandica, Phryma leptostacha, Podophyllum peltatum, Circaea quadrisulcata, Sanguinaria canadensis, Galium circaezans, Geranium maculatum and Osmorhiza claytonia. With their similar niches, such understory species may be exposed to comparable levels of invasive species.

Given the importance of ginseng and the current threat of invasive plant species, the purpose of this study was to address the following questions: (1) What is the level of exposure of ginseng populations and individuals to invasive plant species? (2) What species of invasive plants are most abundant within ginseng populations? (3) Are all size classes of ginseng equally exposed to invasive plants or are certain stages more exposed than others? (4) Is presence of invasive species predicted by population size, elevation, latitude, and/or previous harvest?

\section{METHODS}

To assay invasive species, presence/absence data were recorded in 30 natural ginseng populations over the course of two years (2006 and 2007). Two years of censusing were necessary to ensure detection of invasive species that may have been missed inadvertently due to rarity or crypticity. These widely distributed populations 


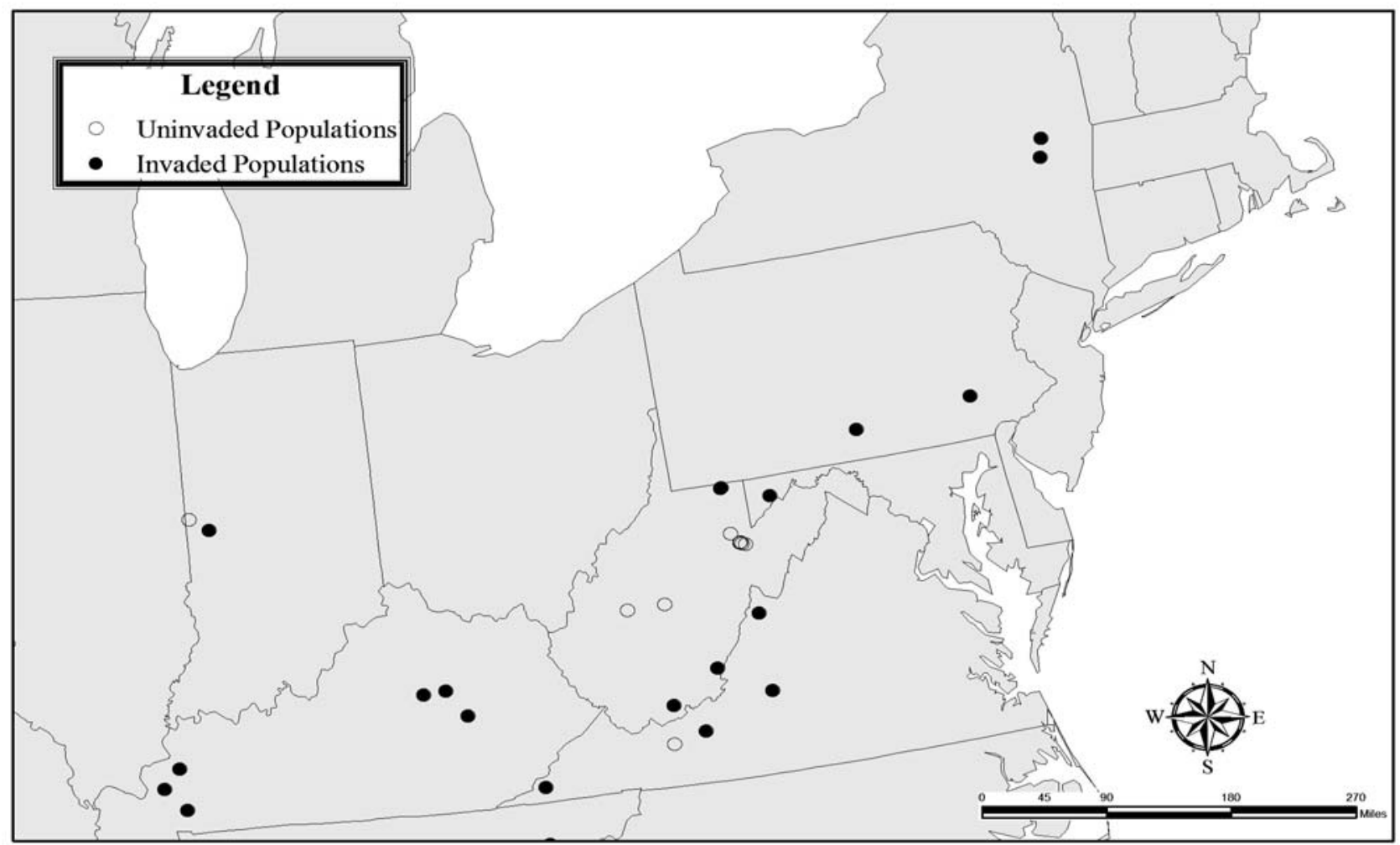

Figure 2.1: Distribution of invaded and uninvaded study populations spread over 7 states in 2007 
were located in seven states (IN, KY, MD, NY, PA, VA, and WV), covering much of the breadth of ginseng's natural range (Fig. 2.1). The surveys were performed in mid to late May when the individual ginseng plants had fully emerged from dormancy and were least likely to have been deer browsed. Dormant plants were not surveyed; however plants that had emerged but had evidence of deer browse were included. Most populations were located within mixed mesophytic forests with tree species such as sugar maple (Acer saccharum) and tulip poplar (Liriodendron tulipifera) dominating the overstory (Table 2.1). Populations were located in a range of elevations and latitudes representative of the wide variety of habitats that ginseng occupies (Table 2.1). Furthermore, a few populations were located within marginal or atypical habitat for ginseng and some ginseng populations have been previously harvested.

The invasive species survey was done while censusing ginseng for a long-term demographic study. Within each population, plants were located each year using a series of digital photographs, distances and directions to individuals that were cryptically tagged with engraved aluminum nails. New seedlings and new plants were given new nails and identification numbers as they were found, and the leaf number of each plant was recorded to delineate size classes. A total of 4,540 ginseng were surveyed in 2006 and 4,279 in 2007.

Traditionally, presence-absence surveys utilize randomly placed transects or quadrats to sample species occurrence (McIntyre et al. 1995; Weber and Gibson 2007). However, the aim of this paper was to examine the level of exposure of only ginseng plants. Therefore, invasive species' presence data were collected on a plant-by-plant 
Table 2.1: Attributes of study populations.

\begin{tabular}{|c|c|c|c|c|c|}
\hline State & Population & $\begin{array}{c}\text { Known harvest } \\
\text { history }\end{array}$ & Overstory & Elevation (m) & Latitude $^{1}$ \\
\hline WV & 1 & $\mathrm{Y}$ & $\mathrm{MM}$ & 775 & 37.4 \\
\hline WV & 2 & $\mathrm{~N}$ & $\mathrm{AH}$ & 764 & 39.1 \\
\hline $\mathrm{KY}$ & 3 & $\mathrm{~N}$ & MM & 314 & 37.5 \\
\hline WV & 4 & $\mathrm{~N}$ & $\mathrm{AH}$ & 758 & 39.0 \\
\hline MD & 5 & $\mathrm{Y}$ & MM & 577 & 39.5 \\
\hline WV & 6 & $\mathrm{Y}$ & MM & 370 & 38.5 \\
\hline WV & 7 & $\mathrm{~N}$ & $\mathrm{AH}$ & 630 & 39.0 \\
\hline $\mathrm{KY}$ & 8 & $\mathrm{Y}$ & MM & 148 & 37.3 \\
\hline PA & 9 & $\mathrm{Y}$ & MM & 146 & 40.2 \\
\hline KY & 10 & $\mathrm{~N}$ & MM & 276 & 37.6 \\
\hline KY & 11 & $\mathrm{Y}$ & MM & 217 & 37.8 \\
\hline WV & 12 & $\mathrm{~N}$ & MM & 618 & 37.8 \\
\hline NY & 13 & $\mathrm{~N}$ & $\mathrm{AH}$ & 466 & 42.5 \\
\hline VA & 14 & $\mathrm{Y}$ & MM & 743 & 36.9 \\
\hline PA & 15 & $\mathrm{~N}$ & MM & 230 & 40.0 \\
\hline WV & 16 & $\mathrm{Y}$ & MM & 258 & 38.5 \\
\hline KY & 17 & $\mathrm{~N}$ & MM & 106 & 37.1 \\
\hline VA & 18 & $\mathrm{~N}$ & $\mathrm{AH}$ & 1073 & 38.2 \\
\hline VA & 19 & $\mathrm{Y}$ & $\mathrm{OH}$ & 595 & 37.4 \\
\hline WV & 20 & $\mathrm{Y}$ & MM & 538 & 39.7 \\
\hline WV & 21 & $\mathrm{Y}$ & MM & 526 & 39.7 \\
\hline VA & 22 & $\mathrm{Y}$ & MM & 591 & 37.1 \\
\hline WV & 23 & $\mathrm{~N}$ & MM & 333 & 39.6 \\
\hline KY & 24 & $\mathrm{~N}$ & MM & 167 & 36.9 \\
\hline NY & 25 & $\mathrm{Y}$ & $\mathrm{AH}$ & 204 & 42.7 \\
\hline IN & 26 & $\mathrm{Y}$ & MM & 194 & 39.9 \\
\hline IN & 27 & $\mathrm{~N}$ & MM & 171 & 40.0 \\
\hline WV & 28 & $\mathrm{~N}$ & $\mathrm{AH}$ & 761 & 39.1 \\
\hline WV & 29 & $\mathrm{~N}$ & MM & 783 & 39.1 \\
\hline VA & 30 & $\mathrm{~N}$ & $\mathrm{OH}$ & 591 & 37.0 \\
\hline $\begin{array}{c}7 \\
\text { states }\end{array}$ & $\begin{array}{c}30 \\
\text { populations }\end{array}$ & $46 \%$ harvested & $\begin{array}{c}67 \% \mathrm{MM} \\
27 \% \mathrm{AH} \\
6 \% \mathrm{OH}\end{array}$ & & \\
\hline
\end{tabular}

Key: ${ }^{1}$ Measured in decimal degrees and rounded for this table to protect location of populations. $\underline{\text { Harvest }}$ history (during census period): $\mathrm{N}=$ none, $\mathrm{Y}=\mathrm{yes}$; Overstory: $\mathrm{MM}=$ mixed mesophytic, $\mathrm{AH}=\mathrm{Allegheny}$ hardwoods, $\mathrm{OH}=$ oak-hickory 
basis to determine the total proportion of individuals exposed to invasive plants as well as the frequency of invasive plants at each site. Invasive, herbaceous plants were recorded as present if they fell within a $2 \mathrm{~m}$ radius of a ginseng plant, while shrubs were recorded as present if within $5 \mathrm{~m}$, and trees if within $10 \mathrm{~m}$. These distances were conservatively chosen to represent the outer limits of distances at which the invasive plants may competitively or chemically affect ginseng. For example, allelopathic trees such as treeof-heaven not only emit allelochemicals from roots but also from leaf litter (Heisey 1990; Heisey 1996) which would make $10 \mathrm{~m}$ a reasonable distance for possible effects. These distances may overestimate the number of plants that presently affect ginseng but conservatively estimate the number that are 'poised' to potentially impact ginseng in the near future. For instance, garlic mustard has been found to spread $5.4 \mathrm{~m} / \mathrm{yr}$ (Nuzzo 1999). Without knowing the competitive reach of each invasive species, this first approximation of competitive range was made as a compromise between these two factors.

Data on invasive species' presence were used to calculate the proportion of ginseng populations with invasive species present as well as the proportion of ginseng individuals with an invasive plant within a potentially competitive range. Absence of invasive species in a population does not imply that they are not present at the site; only that there were none within competitive range of ginseng. Relative abundance of the invasive species was compared using the Panax-centric presence data as well. For those populations that had invasives, the proportion of each ginseng size class that had invasives within competitive range was calculated. Size categories were based on the leaf number (1,2, and 3 or more), roughly corresponding to seedlings, juveniles and 
adults (Charron and Gagnon 1991; McGraw and Furedi 2005). Data were then analyzed using a log-likelihood test to determine if there were differences among populations and size classes ('main effects' in the model) in proportion of individual ginseng plants with invasive species in competitive range. The interaction term was included to determine whether size class differences varied among populations.

Presence of invasive species was related to ginseng population size, elevation, and latitude using logistic regression to test the hypothesis that these environmental variables would predict presence of invasives. A priori, we expected that small populations and those from high elevations and latitudes would have a lower probability of invasive species presence. For populations with invasive species, we used linear regression to examine the number of ginseng plants with an invasive in range as a function of population size as well as the proportion of ginseng plants with invasives in range as a function of population size. Finally, a log-likelihood test was used to determine if the presence of harvest would predict presence of invasive species.

\section{RESULTS}

Invasive plant species were found in 19 out of 30 ginseng populations (63\%) in 2006 and 21 out of 30 ginseng populations (70\%) in 2007 (Table 2.2, Fig. 2.1). Furthermore, 10 populations in 2006 had more than one invasive species while 13 populations had multiple invasive species in 2007 (Table 2.2). In 2006, one site, population 9, contained 7 different invasive species (Table 2.2).

As with populations, exposure of ginseng individuals within was high. A total of 1,329 out of $4,540(29.3 \%)$ ginseng individuals had an invasive plant within competitive 
Table 2.2: Proportion of ginseng individuals with invasive plant within competitive range in each population in 2006 and 2007.

\begin{tabular}{|c|c|c|c|}
\hline Population & $\begin{array}{c}2006 \\
\text { Invaded/N }\end{array}$ & $\begin{array}{c}2007 \\
\text { Invaded/N }\end{array}$ & Invasive Species Present \\
\hline 1 & $57 / 63$ & $44 / 44$ & $\mathrm{BT}^{1}, \mathrm{RM}$ \\
\hline 2 & $0 / 34$ & $0 / 22$ & N/A \\
\hline 3 & $0 / 433$ & $3 / 344$ & $\mathrm{RM}^{2}$ \\
\hline 4 & $26 / 86$ & $29 / 87$ & BT \\
\hline 5 & $104 / 175$ & $91 / 184$ & AP \\
\hline 6 & $0 / 60$ & $0 / 71$ & N/A \\
\hline 7 & $0 / 11$ & $0 / 10$ & N/A \\
\hline 8 & $0 / 48$ & $19 / 38$ & $\mathrm{LO}^{2}$ \\
\hline 9 & $93 / 100$ & $90 / 102$ & $\mathrm{AC}^{1}, \mathrm{AP}, \mathrm{BT}, \mathrm{EU}^{1}, \mathrm{LS}, \mathrm{LO}, \mathrm{RM}$ \\
\hline 10 & $34 / 91$ & $44 / 93$ & LJ, RM \\
\hline 11 & $104 / 281$ & $114 / 155$ & $\mathrm{LO}, \mathrm{MV}^{1}, \mathrm{RM}$ \\
\hline 12 & $14 / 151$ & $27 / 138$ & $\mathrm{BT}, \mathrm{EA}^{2}, \mathrm{LO}, \mathrm{RM}$ \\
\hline 13 & $7 / 320$ & $3 / 342$ & BT \\
\hline 14 & $44 / 213$ & $44 / 153$ & $\mathrm{MV}^{1}, \mathrm{RM}$ \\
\hline 15 & $347 / 387$ & $421 / 485$ & $\mathrm{AA}, \mathrm{BT}, \mathrm{EU}^{1}, \mathrm{MV}^{1}, \mathrm{RM}, \mathrm{RP}$ \\
\hline 16 & $5 / 97$ & $0 / 94$ & $\mathrm{RM}$ \\
\hline 17 & $10 / 99$ & $53 / 65$ & $\mathrm{AA}^{2}, \mathrm{LO}, \mathrm{LJ}$ \\
\hline 18 & $9 / 55$ & $20 / 45$ & $\mathrm{AP}, \mathrm{LO}^{2}, \mathrm{RM}^{2}$ \\
\hline 19 & $251 / 311$ & $239 / 241$ & $\mathrm{AP}, \mathrm{LO}, \mathrm{RM}$ \\
\hline 20 & $48 / 126$ & $51 / 124$ & $\mathrm{RM}$ \\
\hline 21 & $32 / 407$ & $39 / 407$ & $\mathrm{AA}^{2}, \mathrm{BT}, \mathrm{RM}$ \\
\hline 22 & $114 / 130$ & $68 / 112$ & $\mathrm{BT}, \mathrm{LO}, \mathrm{LJ}^{2}, \mathrm{RM}$ \\
\hline 23 & $0 / 162$ & $0 / 104$ & N/A \\
\hline 24 & $0 / 63$ & $126 / 126$ & $\mathrm{AA}^{2}$ \\
\hline 25 & $22 / 76$ & $33 / 102$ & $\mathrm{BT}, \mathrm{LO}^{2}$ \\
\hline 26 & $8 / 131$ & $26 / 126$ & $\mathrm{AP}^{2}, \mathrm{LO}^{2}, \mathrm{RM}$ \\
\hline 27 & $0 / 160$ & $0 / 168$ & N/A \\
\hline 28 & $0 / 100$ & $0 / 103$ & N/A \\
\hline 29 & $0 / 136$ & $0 / 159$ & N/A \\
\hline 30 & $0 / 33$ & $0 / 35$ & N/A \\
\hline Total & $1329 / 4540$ & $1584 / 4279$ & \\
\hline
\end{tabular}

Key: ${ }^{1}=2006$ only ${ }^{2}=2007$ only

$\mathrm{AA}=$ Ailanthus altissima, $\mathrm{AC}=$ Acer platanoides, $\mathrm{AP}=$ Alliaria petiolata, $\mathrm{BT}=$ Berberis thunbergii,

$\mathrm{EU}=$ Eleagnus umbellata, $\mathrm{EA}=$ Euonymus alatus, $\mathrm{LS}=$ Ligustrum spp., $\mathrm{LJ}=$ Lonicera japonica,

$\mathrm{LO}=$ Lonicera spp., $\mathrm{MS}=$ Microstegium vimineum, $\mathrm{RM}=$ Rosa multiflora, $\mathrm{RP}=$ Rubus phoenicolasius 
range in 2006 and 1,584 out of $4279(37.0 \%)$ ginseng were exposed to invasive plants in 2007. Twelve invasive species were found within the study populations. Overall, two herbaceous invasive species (Alliaria petiolata and Microstegium vimineum), eight shrub species (Lonicera japonica, Lonicera sp., Rosa multiflora, Berberis thunbergii, Rubus phoenicolasius, Elaeagnus umbellata, Euonymus alatus, Ligustrum spp.), and two tree species (Acer platanoides and Ailanthus altissima) were found within ginseng populations. Due to the timing of the survey and the lack of reproductive structures, the bush honeysuckles and privet were not identified to the species level. Therefore, the bush honeysuckle category may have included up to four species (Lonicera tatarica, $L$. morrowii, L. $x$ bella and L. maackii) and the privet category could have included either Ligustrum obtusifolum or Ligustrum vulgare. The most abundant invasive species at the individual and population levels for both years were multiflora rose (Rosa multiflora) and Japanese barberry (Berberis thunbergii) (Table 2.2, Fig. 2.2).

Different size classes of ginseng were not equally exposed to invasive species, however the specific pattern varied among populations (population $\mathrm{x}$ size class of ginseng interaction; 2006, $\mathrm{L}-\mathrm{R}=103.049, \mathrm{p}<0.0001 ; 2007, \mathrm{~L}-\mathrm{R}=83.2903, \mathrm{p}<0.0001)$. In 2006 and 2007, sites such as 1, 9 and 15 all had greater than $80 \%$ invasion in all classes (Figs. 2.3, 2.4). In contrast, sites such as 4 and 18 had higher proportions of seedlings with invasives in range while population 11, 12 and 20 had more adults exposed in 2006 (Fig. 2.3). In 2007, populations 19 and 24 also had greater than $80 \%$ invasion (Fig. 2.4). Also in 2007 , population 4 had mostly seedlings exposed while population 18 had mostly juveniles and populations 11 and 20 had more adults (Fig. 2.4). 


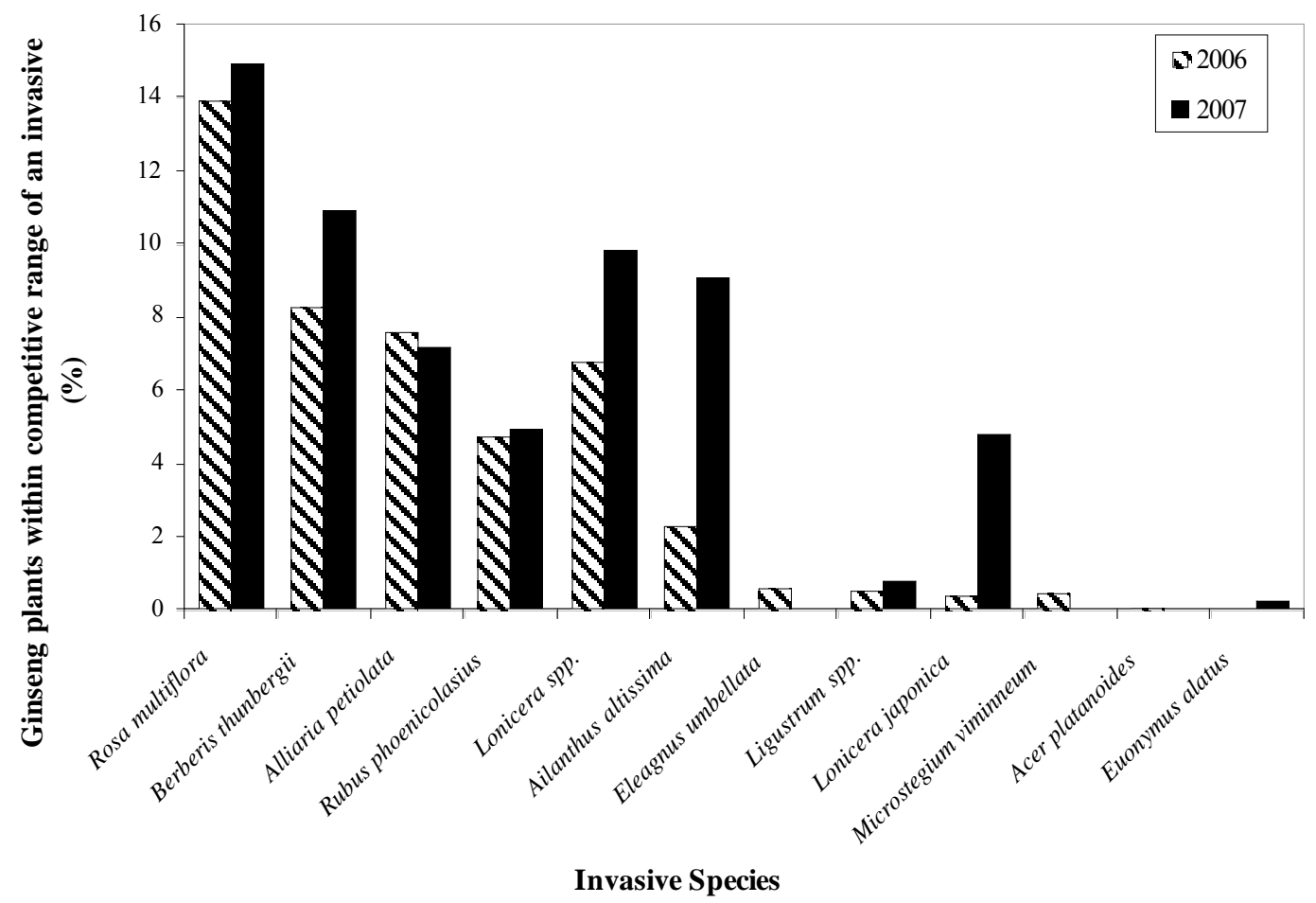

Figure 2.2: Percentage of individual ginseng plants having a particular invasive within competitive range for $2006(\mathrm{~N}=4,540)$ and $2007(\mathrm{~N}=4,279)$ 


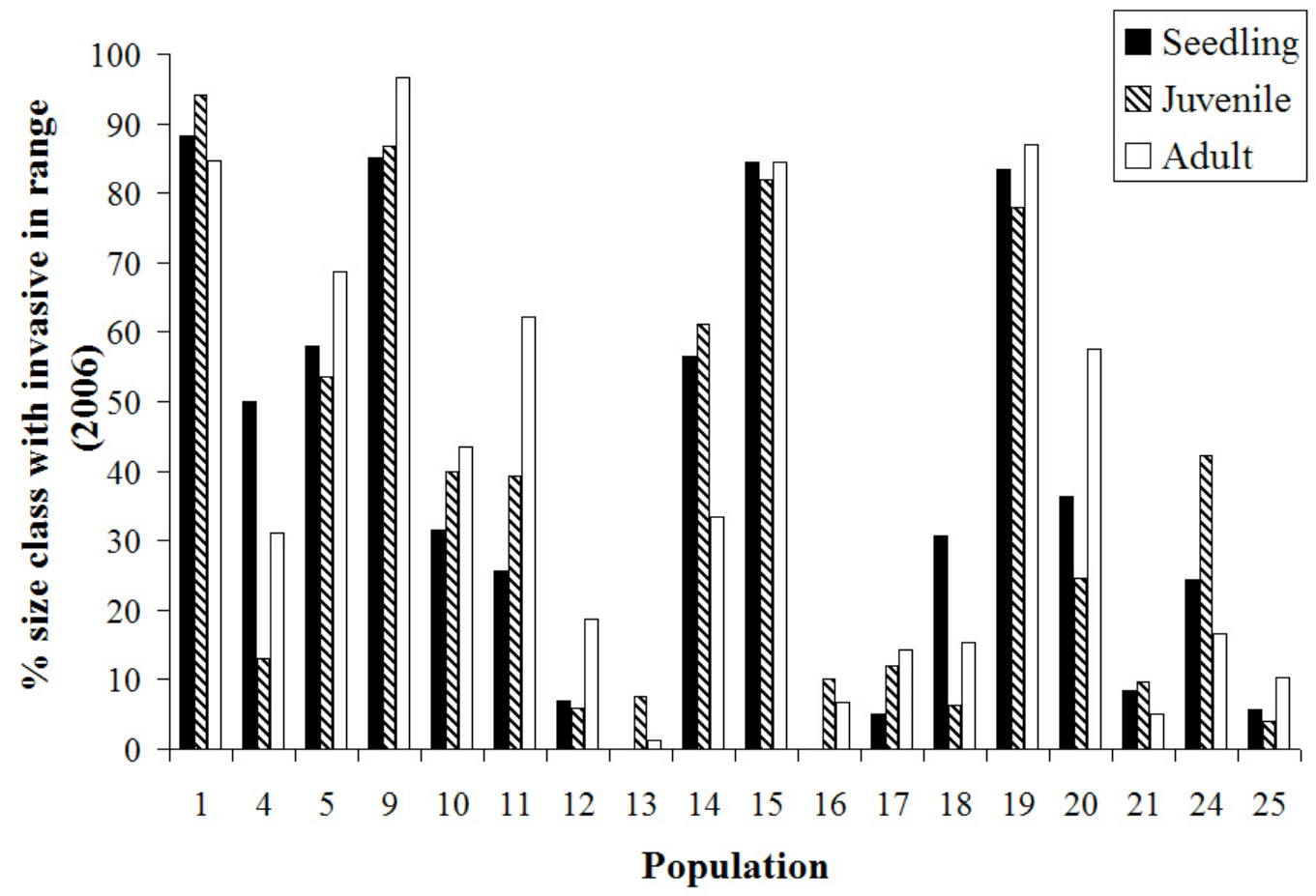

Figure 2.3: Percentage of individuals within ginseng size classes having invasives in competitive range in 2006 


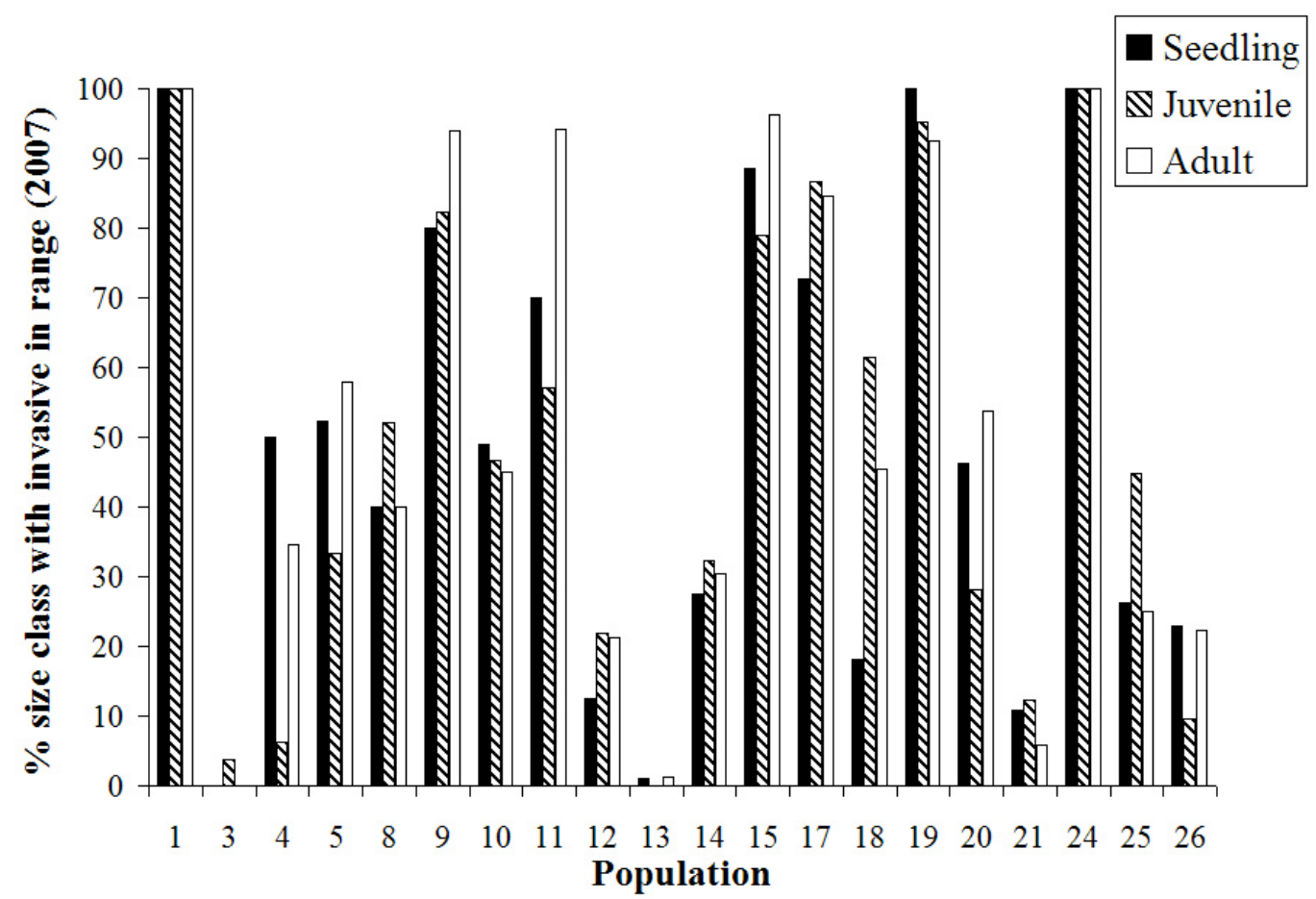

Figure 2.4: Percentage of individuals within ginseng size classes having invasives in competitive range in 2007 
In 2006 , there was no clear propensity for larger populations to contain invasive species $\left(\chi^{2}=2.191, p=0.1388\right)$, however in 2007 , there was a significant positive relationship between population size and presence of invasives $\left(\chi^{2}=4.726, p=0.0297\right)$. For populations with invasive plants, the number of ginseng individuals with invasives in range was positively related to population size in 2006 (slope $=0.429468, \mathrm{p}=0.0199)$ and 2007 (slope $=0.3899218, \mathrm{p}=0.0156)$. However, in invaded populations, the proportion of individuals with invasives in range was not related to population size in either year (slope $=0.0005, \mathrm{p}=0.9469 ;$ slope $=-0.0005, \mathrm{p}=0.3903)$.

Elevation did not significantly affect the presence of invasive species in 2006 or $2007\left(\chi^{2}=0.012207, p=0.9120 ; \chi^{2}=1.2622, p=0.2612\right)$, nor did latitude $\left(\chi^{2}=0.609945\right.$, $p=.4348 ; \chi^{2}=1.2622, p=0.2612$ ). In 2006 and 2007, previously harvested populations were more likely to contain invasive species $(\mathrm{L}-\mathrm{R}=6.016, \mathrm{p}=0.0142 ; \mathrm{L}-\mathrm{R}=5.6599$, $\mathrm{p}=0.0174)$.

\section{DISCUSSION}

Documenting the presence of an invasive plant species in a community is of limited value with respect to estimating potential impact. Using individual plants of a native species as a phytometer (Antonovics and Primack 1982), however, comes closer to quantifying potential impact. This study is the first attempt to document the level of exposure of a particular understory herb to invasive plant species on a plant-centric basis across much of its range.

Past land use history may explain the presence of invasive plant species (Lundgren et al. 2004), particularly at sites containing multiple invasive species and high numbers of invasion. Population 9 had the highest diversity of invasive species and was 
located in a small tract of land fragmented by housing development which may explain the presence of ornamental species such as Ligustrum spp. Another population, 1, which contained a high level of Rosa multiflora, was previously disturbed by municipal activity and is also bordered by agricultural fields. In the case of population 15, it had nearby agricultural fields. While these populations of ginseng were within marginal habitats for the species, in such environments invasive species may have a negative consequence for continued persistence. With increased suburban sprawl and forest fragmentation, an increasing fraction of ginseng populations may be found in these environments.

Site-specific factors may explain the differences in invaded size classes of ginseng by population. Populations 1, 9 and 15 were located within marginal habitat, which could explain the high levels of invasion among all size classes. The high level of invasion among the seedling class at population 18 may have been due to greater recruitment near the edge of the forest, closest to light gaps where many of the invasives reside. In 2006, a higher proportion of seedlings at population 11 had invasives in range, while a recent harvest in 2007 removed half of the adults from the population in a portion of the site that was least invaded.

The increased likelihood that larger populations of ginseng were invaded and contained multiple invasive species was most likely due to the fact that larger populations covered more area, thus increasing the probability of encountering invasive species. If this were not the case, then the proportion of individuals with invasives in range would have also been a function of population size, and this was not found.

Harvested populations also tended to have invasive species. Removal of ginseng for harvest disturbs the litter layer and may facilitate colonization by invasives or other 
species, depending on availability of propagules. How species react to disturbance depends not only on characteristics of the disturbance (size, intensity, and timing) but also the attributes of surrounding species (Hobbs and Huenneke 1992). Several of the harvested populations were in atypical and marginal habitat, close to edges in which humans could easily access, harvest and disturb the landscape to allow invasive colonization. Species such as A. petiolata are not facilitated by litter disturbance (Meekins and McCarthy 2001), yet others such as M. vimineum have been found to positively respond (Oswalt and Oswalt 2007). Humans may further function as vectors for invasive plants by accidentally importing seeds on their shoes, clothing and equipment.

Invasives such as Rosa multiflora (affecting 13.9-14.9\% of ginseng plants) and Berberis thunbergii (affecting $8.3-10.9 \%$ of ginseng plants) were the most ubiquitous invaders among ginseng individuals and populations. R. multiflora has been found to be one of the most frequent invasive plants in an old growth forest in Indiana (Weber and Gibson 2007), and within forest fragments (Brothers and Spingam 1992). Another study found both invasive species to be dominant across their sites (Lundgren et al. 2004). $R$. multiflora has been found to create dense thickets which may competitively exclude native species, while Berberis thunbergii may alter the microbial community structure within soils in as little as 3 months (Kourtev et al. 2002; Kourtev et al. 2003).

Dispersal patterns of the invasives found on ginseng sites may explain their presence in forest interiors. Birds and mammals have been found to disperse many of the invasive honeysuckles, R. multiflora and B. thunbergii (Vellend 2002; Myers et al. 2004; Ehrenfeld 1997). Indeed, some invasive plants were originally planted for wildlife forage 
(Dyess et al. 1994; Ehrenfeld 1997; Handley 1945; Steavenson 1946). L. tatarica was even found to be preferentially selected by frugivores (Drummond 2005). Long distance dispersal and ability to invade canopy gaps by species such as A. altissima may also explain presence in forest interiors (Knapp and Canham 2000; Landenberger et al. 2007).

The abundance of particular invasive species changed between 2006 and 2007. Although there were exceptions, most differences between years were not interpreted as reflecting spread or decline of the invasive species. In the case of bush honeysuckle (Lonicera sp.), more was found in 2007 , but this is likely due to increased detection of this species group by surveyors after unexpectedly encountering them in the first year. However, the greater presence of Ailanthus altissima in 2007 than in 2006 was due to new colonization by seedlings in four previously uninvaded populations. Lonicera japonica, known to produce dense mats of vegetation which excludes native seedlings (Hardt 1986; Myster and Pickett 1992), had increased presence around ginseng individuals between 2006 and 2007. The absence of Microstegium vimineum, Acer platanoides, and Euonymus alatus in 2007 was due to the dormancy or death of ginseng individuals near them, though the invasives were still present. The same occurence happened in population 16 , in which no invasives were recorded in competitive range of ginseng in 2007. Between 2006 and 2007, a late frost also caused many ginseng individuals to go dormant or die, which caused a decline in total ginseng population numbers and potentially an increase in the percentage of invasives. Several populations were further harvested between the two years which could also account for changes in invasive presence/absence. 
Several invasive plants found in ginseng populations have allelopathic properties. L. maackii extracts from leaves and roots on seed germination revealed significant decreases in germination of 3 herb species (Dorning and Cipollini 2005). A. altissima also has been found to reduce growth of seedlings from several crop species (De Feo et al. 2003; Heisey 1990; Heisey 1996). Garlic mustard is another allelopathic species whose extracts were found to reduce germination and colonization of mycorrhizae of several crop species (Prati and Bossdorf 2004; Roberts and Anderson 2001) as well as reduced the growth of arbuscular-mycorrhizal fungi (AMF) dependent tree species (Stinson et al. 2006). Changes in arbuscular-mycorrhizal fungi can have not only individual effects on host plants but also population and community level impacts (Smith and Read 1997).

Overall, a high level of invasion was found within ginseng populations and within competitive ranges of ginseng. Given ginseng's widespread distribution within eastern deciduous forests, it is probable that other similar understory plants experience a comparable level of exposure. The presence of multiple invasive species within ginseng populations also presents the possibility of inter-invasive facilitation through factors such as soil modification (Jordan et al. 2007). Alteration of soils by allelopathy (Heisey 1990; Heisey 1996; Prati and Bossdorf 2004; Roberts and Anderson 2001; Stinson et al. 2006) or through litter inputs (Wolfe and Klironomos 2005) may change nutrients in soil which could impact vegetative and reproductive success in ginseng (Shahi 2007). Interactions between invasive species and ginseng may have undesirable effects on demography of ginseng, especially in addition to the current pressures of harvest and deer browse. 


\section{REFERENCES}

Anderson RC, Fralish JS, Armstrong JE (1993) The ecology and biology of Panax quinquefolium L. (Araliaceae) in Illinois. Am Midl Nat 129:357-372.

Antonovics J, Primack RB (1982) Experimental ecological genetics in Plantago. VI. The demography of seedling transplants of $P$. lanceolata. J Ecol 70:55-75.

Bailey B (1999) Social and economic impacts of wild harvested products. Ph.D. Dissertation, West Virginia University, Morgantown, WV.

Bais, HP, Vepachedu R, Gilroy S, Callaway RM, Vivanco JM (2003) Allelopathy and exotic plant invasion: from molecules and genes to species interactions. Science 301(5):1377-1380.

Brothers TS, Spingam A (1992) Forest fragmentation and alien plant invasion of central Indiana old-growth forests. Conserv Biol 6(1): 91-100.

Callaway RM, Aschehoug ET (2000) Invasive plants versus their new and old neighbors: a mechanism for exotic invasion. Science 290:521-523.

Callaway RM, Ridenour WM (2004) Novel weapons: invasive success and the evolution of increased competitive ability. Front Ecol 2(8):436-443.

Charron D, Gagnon D (1991) The demography of northern populations of Panax quinquefolium (American ginseng). J Ecol 79(2):431-445.

Cruse-Sanders JM, Hamrick, JL (2004) Spatial and genetic structure within populations of wild American ginseng (Panax quinquefolius L. Araliaceae). J of Hered 95(4):309-321.

De Feo V, De Martino L, Quaranta E, Pizza C (2003) Isolation of phytotoxic compounds from tree-of-heaven (Ailanthus altissima Swingle). J Agric Food Chem 51(5): $1177-1180$.

Dorning M, Cipollini D (2005) Leaf and root extracts of the invasive shrub, Lonicera maackii, inhibit seed germination of three herbs with no autotoxic effects. Plant Ecol 184(2):287-296.

Drummond BA (2005) The selection of native and invasive plants by frugivorous birds in Maine. Northeast Nat 12(1):33-44.

Dyess JG, Causey MK, Striblin HL, Lockaby BG (1994) Effects of fertilization on production and quality of Japanese honeysuckle. South J of Appl For 18: 68-71. 
Ehrenfeld JG (1997) Invasion of deciduous forest preserves in the New York metropolitan region by Japanese barberry (Berberis thunbergii DC). J Torrey Bot Soc 124(2): 210-215.

Ehrenfeld JG, Scott NS (2001) Invasive species and the soil: effects on organisms and ecosystem processes. Ecol Appl 11(5): 1259-1260.

Handley CO (1945) Japanese honeysuckle in wildlife. J of Wildl Manage 9: 261-264.

Hardt RA (1986) Japanese honeysuckle: from "one of the best" to ruthless pest. Arnoldia 25(3): 27-34.

Heisey RM (1990) Allelopathic and herbicidal effects of extracts from Tree of Heaven (Ailanthus altissima). Am J of Bot 77(5): 662-670.

Heisey RM (1996) Identification of an allelopathic compound from Ailanthus altissima (Simaroubaceae) and characterization of its herbicidal activity. Am J Bot 83(2):192-200.

Hobbs RJ, Huenneke LF (1992) Disturbance, diversity, and invasion: implications for conservation. Conserv Biol 6(3): 324-337.

Jordan NR, Larson DL, Huerd SC (2007) Soil modification by invasive plants: effects on native and invasive species of mixed-grass prairies. Biol Invasions 1387-3547.

Knapp LB, Canham CD (2000) Invasion of an old-growth forest in New York by Ailanthus altissima: sapling growth and recruitment in canopy gaps. J Torrey Bot Soc 127: 307-315.

Kolar CS, Lodge DM (2001) Progress in invasion biology: predicting invaders. Trends Ecol Evol 16(4):199-204.

Kourtev PS, Ehrenfeld JG, Haggblom M (2002) Exotic plant species alter the microbial community structure and function in the soil. Ecology 83(11):3152-3166.

Kourtev PS, Ehrenfeld JG, Haggblom M (2003) Experimental analysis of the effect of exotic and native plant species on the structure and function of soil microbial communities. Soil Biol and Biochem 35:895-905.

Landenberger RE, Kota NL, McGraw JB (2007) Seed dispersal of the non-native invasive tree Ailanthus altissima into contrasting environments. Plant Ecol 192(1): 55- 70. 
Lundgren MR, Small CJ, Dreyer, GD (2004) Influence of land use and site characteristics on invasive plant abundance in the Quinebaug highlands of southern New England. Northeast Nat 11(3): 313-332.

Marvier M, Karieva P, Neubert MG (2004) Habitat destruction, fragmentation, and disturbance promote invasion by habitat generalists in a multispecies metapopulation. Risk Anal 24(4): 869-878.

McCarthy B (1997) Response of a forest understory community to experimental removal of an invasive nonindigenous plant (Alliaria petiolata, Brassicaceae). in Luken JO, Thieret JW (ed). Assessment and management of plant invasions. SpringerVerlag, New York. Pp 117-130

McGraw JB, Furedi MA (2005) Deer browsing and population viability of a forest understory plant. Science 307:920-922.

McGraw JB, Sanders SM, Van der Voort ME (2003) Distribution and abundance of Hydrastis canadensis L. (Ranunculaceae) and Panax quinquefolius L. (Araliaceae) in the central Appalachian region. J Torrey Bot Soc 130(2): 62-69.

McIntyre S, Lavorel S, Tremont RM (1995) Plant life-history attributes: their relationship to disturbance response in herbaceous vegetation. J Ecol 83(1): 31-44.

Meekins JF, McCarthy, BC (2001) Effect of environmental variation on the invasive success of a nonindigenous forest herb. Ecol App 11(5):1336-1348.

Mitchell CG, Power AG (2003) Release of invasive plants from fungal and viral pathogens. Nature 421:625-627.

Mooney EH, McGraw JB (2007) Alteration of selection regime resulting from harvest of American ginseng, Panax quinquefolius. Conserv Genet 8:57-67.

Myers JA, Vellend M, Gardescu S, Marks PL (2004) Seed dispersal by white-tailed deer: implications for long-distance dispersal, invasion, and migration of plants in eastern North America. Oecologia 139(1):1432-1939.

Myster RW, Pickett STA (1992) Dynamics of associations between plants in ten old fields during 31 years of succession. J Ecol 80: 291-302.

Nagel JM, Griffin KL (2004) Can gas-exchange characteristics help explain the invasive success of Lythrum salicaria? Biol Invasions 6:101-111.

Nuzzo V (1999) Invasion pattern of the herb garlic mustard (Alliaria petiolata) in high quality forests. Biol Invasions 1:169-179. 
Oswalt CM, Oswalt SN (2007) Winter litter disturbance facilitates the spread of the nonnative invasive grass Microstegium vimineum (Trin.) A. Camus. For Ecol Manage 249(3): 199-203.

Pimentel D, Zuniga R, Morrison D (2005) Update on the environmental and economic costs associated with alien-invasive species in the United States. Ecol Econ $52: 273-288$.

Prati D, Bossdorf O (2004) Allelopathic inhibition of germination by Alliaria petiolata (Brassicaceae). Am J of Bot 91(2):285-288.

Robbins CS (2000) Comparative analysis of management regimes and medicinal plant trade monitoring mechanisms for American ginseng and goldenseal. Conserv Biol $14: 1422-1434$

Roberts KJ, Anderson RC (2001) Effect of garlic mustard [Alliaria petiolata] (Beib. Cavara \& Grande)] extracts on plants and arbuscular mycorrhizal (AM) fungi. Am Mid Nat 146:146-152.

Rose SL, Perry DA, Pilz D, and Schoeneberger MM (1983) Allelopathic effects of litter on the growth and colonization of mycorrhizal fungi. J of Chem Ecol 9(8):11531162.

Seo H, Anderson RC (1990) Effect of soil microbial and mycorrhizal associations on the productivity and photosynthetic rates of Panax quinquefolium L. Myco Soc of Am Newsl 41:4.

Shahi, DP (2007) Effects of density on reproduction and demographic structures of American ginseng (Panax quinquefolius) populations in Ohio. $\mathrm{PhD}$ dissertation. Bowling Green State University; Bowling Green, OH.

Smith SE, Read DJ (1997) Mycorrhizal Symbiosis. San Diego: Academic Press.

Steavenson, HA (1946) Multiflora rose for farm hedges. J Wildl Manage 10(3):227-234.

Stinson KA, Campbell SA, Powell JR, Wolfe BE, Callaway RM, Thelen GC, Hallett SG, Prati D, Klironomos JN (2006) Invasive plant suppresses the growth of native tree seedlings by disrupting belowground mutualisms. PLoS Biol 4(5): 07270731 .

Stolgren TJ, Schell LD, Heuvel BV (1999) How grazing and soil quality affect native and exotic plant diversity in rocky mountain grasslands. Ecol Appl 9:45-64.

Thomson D (2005) Measuring the effects of invasive species on the demography of a rare endemic plant. Biol Invasions 7:615-624. 
United States Department of Agriculture, Natural Resources Conservation Service (2007) The PLANTS Database (http://plants.usda.gov, 11 December 2007). National Plant Data Center, Baton Rouge, LA 70874-4490 USA.

United States Fish and Wildlife Service (2005) Convention permit applications for wild American ginseng harvested in 2005. Washington, D.C., USA.

Van der Voort ME, McGraw JB (2006) Effects of harvester behavior on populations growth rate affects sustainability of ginseng trade. Biol Conserv 130:505-516.

Vellend M (2002) A pest and an invader: white-tailed deer (Odocoileus virginianus Zimm.) as a seed dispersal agent for honeysuckle shrubs (Lonicera L.). Nat Area $\mathbf{J}$ 22(3):230-234.

Vitousek PM, Walker LR, Whiteaker LD, Mueller-Dombois D, Watson PA (1987) Biological invasion by Myrica faya alters ecosystem development in Hawaii. Science 238(4828): 802-804.

Weber JS, Gibson KD (2007) Exotic plant species in old-growth forest in Indiana. Weed Sci 55:299-304.

Wilcove DS, Rothstein D, Dubow J, Philips A, Losos E (1998) Quantifying threats to imperiled species in the United States. Bioscience 48(8):607-615.

Wolfe LM (2002) Why alien invaders succeed: support for the escape-from-enemy hypothesis. Am Nat 160(6):705-711.

Wolfe BE, Klironomos JN (2005) Breaking new ground: soil communities and exotic plant invasion. Bioscience 55(6):477-488.

\section{ACKNOWLEDGMENTS}

Funding for this project was provided by NSF grant DEB-0613611 to J. B. McGraw. We also would like to thank numerous people who contributed to this project, especially landowners, and those assisting with annual censuses - Emily Mooney, Alyssa Hanna, Sara Souther, Adam Martin, Allison Kenyon, Len DiIoia, Anne Lubbers, Mark Guido, David Kazyak and Clare Maloy. 


\section{Chapter III}

COMPETITIVE AND ALLELOPATHIC EFFECTS OF GARLIC MUSTARD (ALLIARIA PETIOLATA) ON AMERICAN GINSENG (PANAX QUINQUEFOLIUS $)^{1}$

This chapter is formatted for submission to the journal Plant Ecology 


\begin{abstract}
Allelopathy may be one mechanism of invasive plant success, yet field studies examining allelopathic effects on native species are uncommon. Therefore, the purpose of this study was to test competitive and allelopathic effects of garlic mustard, an invasive species, on seedlings of an economically important forest herb, American ginseng (Panax quinquefolius), under natural conditions. For comparative purposes, we also examined the potential competitive and allelopathic effects of a native species (striped violet, Viola striata) on ginseng seedlings. To partition the effects of resource competition and chemical suppression via allelopathy, field soils were amended with activated carbon (or left unamended). Activated carbon was found to positively affect several ginseng growth variables as well as biomass of competitors. There was a tendency for ginseng mortality to increase with garlic mustard presence, though activated carbon alleviated this response. Garlic mustard had no significant effect on any ginseng growth variables, while striped violet was found to suppress ginseng shoot length in the absence of activated carbon. Our results show a surprising effect of activated carbon treatment on plant growth, prompting a need for further research on how some species may respond to its use. Our results also suggest that newly invaded ginseng populations with low densities of garlic mustard may be able to withstand its effects, though recruitment within invaded populations may decline.
\end{abstract}

Keywords: American ginseng, garlic mustard, invasive species, allelopathy, Alliaria petiolata, Panax quinquefolius 


\section{INTRODUCTION}

Invasive plant species alter natural ecosystems (Ehrenfeld and Scott 2001;

Vitousek et al. 1987) and reduce native plant recruitment and diversity through competition (McCarthy 1997; Thomson 2005; Stinson et al. 2007). Some invasive plants are allelopathic, releasing chemical compounds into the environment that suppress performance of neighboring plants (Rice 1984). Plants that have co-evolved with an allelopathic species may be less susceptible to allelopathic compounds while newly exposed species (such as those in an invaded range) may exhibit less resistance (Callaway and Aschehoug 2000; Callaway et al. 2008). The noteworthy success of some of the most aggressive invasive plants is attributed to these secondary compounds (Bais et al. 2003; Callaway and Ridenour 2004; Prati and Bossdorf 2004; Stinson et al. 2006; Gomez-Aparicio and Canham 2008; Callaway et al. 2008).

Many previous experiments investigating allelopathy have consisted of bioassays using aqueous plant extracts in petri dishes (Roberts and Anderson 2001; Butcko and Jensen 2002) or sterilized media. While results from bioassays indicate potential interference, their relevance to natural environments is uncertain, especially in the absence of soil (Inderjit and Weston 2000). In field soil environments, allelochemical effects may be either greater or less than observed in vitro. For example, allelochemicals in soils can inhibit fungal mutualists (Roberts and Anderson 2001; Stinson et al. 2006; Callaway et al. 2008) which would amplify negative effects. On the other hand, allelochemicals may be degraded by bacteria much more rapidly in soils, reducing their bioavailability and negating their potential effects (Schmidt 1988). Alteration of soils by allelopathy (Heisey 1990; Heisey 1996; Prati and Bossdorf 2004; Roberts and Anderson 
2001; Stinson et al. 2006) may change nutrient dynamics and ultimately ecosystem properties (Wardle et al. 1998), effects which are excluded from traditional bioassays. The differences between the effects of allelochemicals in vitro versus soils illustrates the need for more field studies of allelochemical effects, of which there have been few (Nilsson 1994; Nilsson et al. 2000; Rich 2004; Gomez-Aparicio and Canham 2008).

One way to test for allelopathy in the field is to amend soils with activated carbon (Nilsson and Zackrisson 1992; Nilsson 1994; Rich 2004). Activated carbon has an affinity for large organic compounds (Cheremisinoff and Morresi 1978; Inderjit and Callaway 2003). These factors have led to the use of activated carbon by several studies to remove or immobilize allelochemicals in the soil; however activated carbon may also cause some nutrient interference (Lau et al. 2008). Several studies have used activated carbon to quantify allelopathic effects (Nilsson 1994; Ridenour and Callaway 2001; Wardle et al. 1998; Callaway and Ascheoug 2000; Prati and Bossdorf 2004; Cipollini et al. 2008). Activated carbon also has been suggested for use as a restoration tool following invasion (Cipollini 2002; Kulmatiski and Beard 2005).

Garlic mustard (Alliaria petiolata) is a Eurasian biennial that has spread rapidly in forests in southern Canada and 36 states in the U.S. (Cavers et al. 1979; Nuzzo 2000; Welk et al. 2002; USDA 2008). This species forms dense, monotypic stands within forest edges, floodplains, undisturbed understories and even old-growth forests (Nuzzo 1993; Nuzzo 1999; Stinson et al. 2006; Weber and Gibson 2007), reducing growth, abundance and diversity of native species (McCarthy 1997; Stinson et al. 2006; Stinson et al. 2007). 
Evidence for the role of allelopathic chemicals in garlic mustard's competitive ability is contradictory or inconclusive. One early study found extracts from garlic mustard did not affect seeds or seedlings of radish, winter rye, hairy vetch and lettuce (McCarthy and Hanson 1998). However, several phytotoxic chemicals such as glycosides, phenolic acids, cyanide, and glucosinolates were isolated from leaf, stem and root extracts of garlic mustard (Vaughn and Berhow 1999; Cipollini 2002; Cipollini et al. 2005; Cipollini and Gruner 2007). A short-term competition study by Meekins and McCarthy (1999) showed that garlic mustard reduced growth of Chestnut oak (Quercus prinus) seedlings, yet was outcompeted by boxelder (Acer negundo) and spotted jewelweed (Impatiens capensis). Removal of garlic mustard increased native diversity in invaded areas (McCarthy 1997; Stinson et al. 2007), suggesting its ability to suppress native recruitment. Growth suppression may be due to competition, allelopathy or both. Prati and Bossdorf (2004) found that garlic mustard contaminated substrate had a greater allelopathic influence on a North American species than on a European congener, supporting the 'novel weapons' hypothesis (Callaway and Aschehoug 2000). Garlic mustard was later shown to reduce growth of mycorrhizal tree seedlings such as red maple and white ash (Stinson et al. 2006) as well as suppress North American arbuscular mycorrhizal fungi (AMF) more than European AMF (Callaway et al. 2008) and ectomycorrhizal fungi (Wolfe et al. 2008). Suppression of fungal mutualists by garlic mustard may have community level impacts in eastern deciduous forests.

American ginseng (Panax quinquefolius L.) is a culturally significant and economically important native medicinal plant found throughout the eastern deciduous forest (Bailey 1999; Robbins 2000; McGraw et al. 2003). Like many other understory 
species, American ginseng forms vesicular arbuscular mycorrhizal associations (VAM) (Seo and Anderson 1990). Concern over the sustainability of harvesting American ginseng spurred its listing under Appendix II of CITES (Convention on International Trade in Endangered Species of Wild Fauna and Flora). Poor harvest practices (Van der Voort and McGraw 2006), deer browse (McGraw and Furedi 2005), inbreeding and reduced genetic diversity within small populations (Cruse-Sanders and Hamrick 2004, Mooney and McGraw 2007) are all factors that may cause decline of ginseng populations. Recently, high levels of invasive plant species, including garlic mustard, have been documented within natural ginseng populations (Wixted and McGraw 2008). Garlic mustard was found in 5 of 30 natural populations, with $7.1 \%$ of the 4,291 censused ginseng plants having garlic mustard within a $2 \mathrm{~m}$ proximity (Wixted and McGraw 2008). Therefore, the objectives of this research were to examine the following questions: 1) Is there evidence for a competitive and/or allelopathic effect of an invasive non-native competitor (garlic mustard) on ginseng seedling survival and growth? 2) Is there evidence for a competitive and/or allelopathic effect of a native competitor (striped violet) on ginseng seedling survival and growth? 3) Is there a differential allelopathic effect of a native and invasive competitor on ginseng seedling survival and growth? Our experiment was designed to answer these questions in a natural field setting to observe how ginseng seedlings, the most vulnerable stage of ginseng growth, could be affected by one generation of garlic mustard (i.e., over two years). 


\section{METHODS}

\section{Site characteristics}

The study site was located on a northeast-facing slope at ca. $580 \mathrm{~m}$ elevation in northern West Virginia. Precise coordinates are withheld for conservation reasons. The soils were appropriate for ginseng since a natural population was found there in a $60-80$ yr old mixed mesophytic, second growth forest dominated by tulip poplar (Liriodendron tulipifera) and black cherry (Prunus serotina) with spicebush (Lindera benzoin) in the understory. The main soil type in the study area was Dekalb stony loam characterized as moderately deep and excessively drained sandstone soils (Soil Survey Staff 2008). The site lacked garlic mustard invasion, although invasions were known from sites nearby $(<$ $2 \mathrm{~km}$ away).

Study Species

Garlic mustard is a biennial that has seeds which germinate in early spring, and seedlings remain in an evergreen basal rosette during the first year of growth (Cavers et al. 1979). During the second year of growth, rosettes rapidly bolt, growing ca. $2 \mathrm{~cm} /$ day between mid-April and mid-May (Anderson et al. 1996). The flowers begin anthesis in early spring (Cavers et al. 1979). From July through October, seeds are passively dispersed and plants senesce. Garlic mustard is self-pollinating, exhibits high rates of seed production (Cavers et al 1979; Anderson et al. 1996) and can thrive in a variety of conditions, all traits contributing to its success.

Striped violet (Viola striata) was chosen as a potential native competitor for ginseng due to the similarity of its leaf shape and size to that of garlic mustard rosettes as well as its abundance within natural ginseng populations (Wixted, pers obs. 2006). 
Striped violet is a perennial understory species found throughout mesic, deciduous forests within the eastern United States (USDA 2008; Strausbaugh and Core 1978). It produces chasmogamous and cleistogamous flowers from April-June, and seeds germinate the following spring (Strausbaugh and Core 1978).

American ginseng is a long-lived perennial herb with a thick taproot attached to a rhizome (Charron and Gagnon 1991). Ginseng seeds germinate following a 19 mo (or more) dormancy period and begin growth in late April to early May (Hackney and McGraw 2001). The 1 leaf seedling phase lasts ca. $1-5$ years. After sufficient root growth, a second leaf will appear to produce a juvenile plant, which may or may not produce flowers (Lewis and Zenger 1982; Charron and Gagnon 1991). Generally, ginseng plants produce a third or fourth leaf within 5-10 y, although plants can be highly variable in maturation rate (Anderson et al. 1993). Most adult ginseng plants flower, but fruit and seed production are sporadic, increasing as plant size increases (Shahi 2007). Experimental Design

In late April 2006, two weeks prior to transplanting, stratified, wild-simulated New York ginseng seeds were germinated in a greenhouse in native soil from the study area. Garlic mustard and striped violet seedlings were collected from a local site in Morgantown, WV and acclimated to the greenhouse.

A $50 \mathrm{~m} \times 50 \mathrm{~m}$ plot was set up in the study area and competition "arenas" $(10 \mathrm{~cm}$ deep x $15 \mathrm{~cm}$ diameter plastic pipe) were buried throughout the original grid at random locations, avoiding only dense fern patches and excessively rocky microsites. Arenas were used to limit root competition from species other than the treatment plant as well as to standardize the amount of soil used for the treatments. Six treatments were set up with 
50 replicates of each: (1) ginseng alone, (2) ginseng with striped violet or (3) ginseng with garlic mustard, planted in either (a) mixed native soil or (b) mixed native soil amended with GRO-SAFE activated carbon (NORIT Americas Inc.). Treatments with activated carbon (AC) were used to remove potential allelopathic influences thereby partitioning these effects from those of resource competition. Activated carbon was added at a rate of $11.3 \mathrm{~g} / \mathrm{kg}$ of dried soil, a method and amount similar to a field study in eastern deciduous forests by Rich (2004). Rich's (2004) study examined a dose-response for 3 herbaceous perennial species to determine the amount of AC to add to field soils. The AC concentration, furthermore, was similar to amounts used in studies by Callaway and Aschehoug (2000) and Prati and Bossdorf (2004). Since addition of AC requires substantial disturbance to mix and sieve soil, unamended, native soil was also mixed and sieved. An earlier study by Prati and Bossdorf (2004) found that AC addition did not affect garlic mustard growth or reproduction.

Ginseng seedlings were placed in randomly assigned treatments at the beginning of May 2006 and each arena was given a unique ID. Seedlings that senesced within the first week were replaced because we assumed they died from transplanting stress. Every two weeks throughout the growing season, plants other than the transplants were removed. Deer and other large herbivores were excluded from the experiment with wire mesh cages to ensure adequate sample size, and leaf litter from the site was added to the arenas to prevent unnatural soil drying. To prevent garlic mustard invasion at the study site, siliques were removed prior to dispersal in late June 2007 and dried to allow calculation of total competitor biomass. Garlic mustard plants were harvested at the start of senescence in mid-July 2007 to determine total biomass. At the conclusion of the 
experiment in late August 2007, striped violet was harvested with ginseng seedlings prior to violet senescence. Total biomass of competitors was examined to determine whether $\mathrm{AC}$ would alter the size of competitors, thus interacting in an unanticipated manner with the dependent variable - presence of a competitor.

\section{Dependent variables}

In June 2006 and 2007, after full leaf expansion, leaf area was determined by acquiring digital images of individual ginseng leaves silhouetted against a solid white background with a ruler in the field of view. Shadows were removed in Adobe Photoshop v.7.0 as needed. Leaf area was then quantified using NIH ImageJ v.1.37 (Rasband 2005). Relative growth rate on a leaf area basis $\left(\mathrm{RGR}_{\mathrm{LA}}\right)$ for ginseng was then calculated using equation 1 (McGraw and Garbutt 1990).

Equation 1: $\mathrm{RGR}_{\mathrm{LA}}=\ln ($ leaf area 2007) — $\ln ($ leaf area 2006)

In addition, the number of leaves on each ginseng seedling was also counted in 2007 (the number was always 1 at the end of 2006).

Survival of ginseng seedlings and competitors was recorded at the end of August in 2006 and 2007. At the conclusion of the second growing season, in August 2007, all remaining ginseng and striped violet plants were harvested. If ginseng shoot tissue was not present, then the arena was searched for a viable root with the apical bud still present. After harvest, root tissue of all plants was thoroughly rinsed to remove soil. Ginseng seedlings were separated into root and shoot portions. The length of each portion was then measured before drying at $65^{\circ} \mathrm{C}$ for $48 \mathrm{hr}$. The root to shoot ratio was also calculated to test for biomass allocation differences among treatments. Any ginseng 


\begin{tabular}{|c|c|c|c|}
\hline & & Stripec & Presence \\
\hline & & - & + \\
\hline & - & $\mathrm{N}=50$ & $\mathrm{~N}=50$ \\
\hline Presence & + & $\mathrm{N}=50$ & $\mathrm{~N}=50$ \\
\hline
\end{tabular}

b

Garlic Mustard Presence

\begin{tabular}{cc|c|c|}
\multicolumn{1}{c}{ AC } & \multicolumn{1}{c}{-} & + \\
\cline { 2 - 3 } Presence & + & $\mathrm{N}=50$ & $\mathrm{~N}=50$ \\
\cline { 2 - 3 } & $\mathrm{N}=50$ & $\mathrm{~N}=50$ \\
\cline { 2 - 3 } & &
\end{tabular}

C

\section{Competitor Iden tity}

\begin{tabular}{|c|c|c|c|}
\hline \multirow{3}{*}{$\begin{array}{c}\mathrm{AC} \\
\text { Presence }\end{array}$} & & Striped Violet & Garlic Mustard \\
\hline & & $\mathrm{N}=50$ & $\mathrm{~N}=50$ \\
\hline & + & $\mathrm{N}=50$ & $\mathrm{~N}=50$ \\
\hline
\end{tabular}

Figure 3.1: Three two-way factorial permutations of the six treatments examining a) differential effects of violet presence with and without activated carbon (AC), b) differential effects of garlic mustard presence with and without AC, and c) differential effects of the native striped violet and the invasive garlic mustard as a function of $\mathrm{AC}$ treatment. 
seedlings which lacked shoot tissue at the conclusion of the experiment were excluded from root length, root mass, root:shoot ratio and total biomass analyses.

\section{Data analysis}

The experimental design permitted several analyses. In the first two analyses, the data were analyzed as two 2-way factorials, separately for the two competitor species, with competitor presence and AC treatment as main effects (Fig. 3.1a, b). These analyses were used to determine if there was a competitive (competitor main effect) or allelopathic effect (competitor x AC interaction) of either competitor. In the third analysis, only the competition treatments were examined with $\mathrm{AC}$ and competitor species as the main effects. The third set of analyses was used to determine the relative effect of the native or invasive competitor on ginseng seedling survival and growth in the presence or absence of AC (Fig. 3.1c). Log-likelihood tests were used to analyze seedling survival and leaf size fate (one vs. two leaves in 2007), and ginseng size and growth variables were analyzed using a two-way ANOVA. Biomass of the competitor was also analyzed using a two-way ANOVA with competitor identity and AC as the main effects. Finally, ANCOVAs were used for the violet, garlic mustard and the combined competition treatments to determine whether the effect of competitor size (continuous) on ginseng biomass varied depending on $\mathrm{AC}$ treatment (nominal). Data were log transformed if residuals failed meet the assumption of normality. A Tukey-Kramer HSD post hoc test was used after ANOVAs to compare means among levels for significant model effects. 

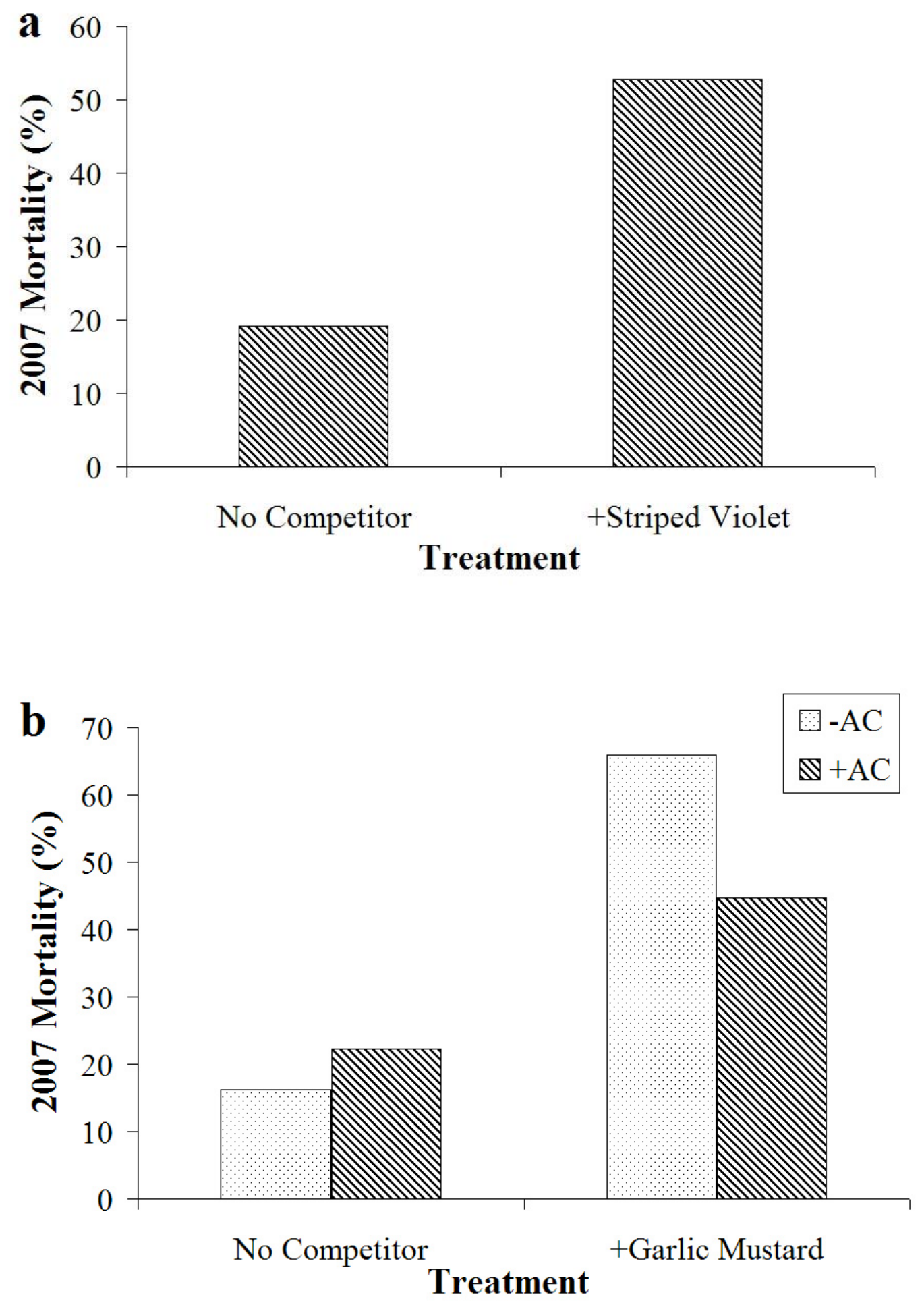

Figure 3.2: (a) Effect of striped violet presence on ginseng seedling mortality in 2007 and (b) differential effect of garlic mustard on ginseng seedling mortality (2007) depending on $\mathrm{AC}$ treatment after two growing seasons. 


\section{RESULTS}

Native competitor effect on ginseng seedlings

In the first growing season (2006), ginseng mortality was not significantly affected by the presence of AC or the addition of striped violet (analyses of the subset of treatments in Fig. 3.1a). However, by the end of the second season (2007), ginseng seedling mortality was higher in striped violet treatments with or without $\mathrm{AC}$ in the soil (competitor main effect; L-R $\chi^{2}=23.17, \mathrm{p}<0.0001$; Fig. 3.2a). The frequency of ginseng seedlings progressing from the one leaf to the two leaf stage in 2007 was significantly higher in AC treatments (AC main effect; L-R $\chi^{2}=7.60, \mathrm{p}=0.0058$ ), and there was a tendency for ginseng leaf number to increase more in the absence of striped violet (competitor * AC interaction; L-R $\chi^{2}=2.81, \mathrm{p}=0.0931$ ). The addition of striped violet did not significantly affect ginseng growth variables in the surviving ginseng seedlings (Table 3.1). AC positively affected ginseng root length (25\%), shoot mass (45\%), root mass $(39 \%)$, total biomass $(36 \%)$ and the relative growth rate of leaf area $(67 \%)$ for ginseng seedlings whether violet competitors were present or not (AC main effect; Tables 3.1, 3.2). The root: shoot ratio also was not significantly affected by AC or striped violet presence (Table 3.1). In the absence of AC, striped violet suppressed ginseng shoot length, but this effect was not observed in the presence of AC (competitor * AC interaction; $F=8.70, \mathrm{p}=0.0040 ;$ Fig. 3.3).

Invasive competitor effect on ginseng seedlings

In analyzing the effects of the invasive garlic mustard (Fig. 3.1b), we found that ginseng mortality was not significantly affected by AC or garlic mustard in 2006. However, in 2007, seedling mortality was 2.5 times higher in garlic mustard treatments 
Table 3.1: ANOVA summary table; significant values $(\mathrm{p}<0.05)$ are bolded while italicized values depict a trend $(0.05<\mathrm{p}<0.10)$. All dependent variables except the relative growth rate of leaf area were log transformed.

\begin{tabular}{|c|c|c|c|c|c|c|c|c|}
\hline & Effect & $\begin{array}{c}\text { Shoot } \\
\text { Length }\end{array}$ & $\begin{array}{c}\text { Root } \\
\text { Length }\end{array}$ & $\begin{array}{l}\text { Shoot } \\
\text { Mass }\end{array}$ & $\begin{array}{l}\text { Root } \\
\text { Mass }\end{array}$ & $\begin{array}{l}\text { Root: } \\
\text { Shoot } \\
\text { Ratio }\end{array}$ & $\begin{array}{c}\text { Total } \\
\text { Biomass }\end{array}$ & $R G R_{L A}$ \\
\hline \multirow{3}{*}{$\begin{array}{c}\text { Striped } \\
\text { Violet }\end{array}$} & $\begin{array}{c}\text { Competitor } \\
(+/-)\end{array}$ & $\mathrm{p}=0.3591$ & $\mathrm{p}=0.5699$ & $\mathrm{p}=0.5393$ & $\mathrm{p}=0.4003$ & $\mathrm{p}=0.2937$ & $\mathrm{p}=0.4293$ & $\mathrm{p}=0.2721$ \\
\hline & $\begin{array}{l}\mathrm{AC} \\
(+/-)\end{array}$ & $p=0.0051$ & $p=0.0019$ & $p=0.0012$ & $p=0.0086$ & $\mathrm{p}=0.1125$ & $p=0.0127$ & $p=0.0074$ \\
\hline & $\begin{array}{c}\text { Competitor } \\
\text { x AC }\end{array}$ & $p=0.0040$ & $p=0.9449$ & $\mathrm{p}=0.1284$ & $\mathrm{p}=0.1235$ & $\mathrm{p}=0.7085$ & $\mathrm{p}=0.1091$ & $\mathrm{p}=0.2933$ \\
\hline \multirow{3}{*}{$\begin{array}{c}\text { Garlic } \\
\text { Mustard }\end{array}$} & $\begin{array}{c}\text { Competitor } \\
(+/-)\end{array}$ & $\mathrm{p}=0.9906$ & $\mathrm{p}=0.3766$ & $\mathrm{p}=0.1046$ & $\mathrm{p}=0.1529$ & $\mathrm{p}=0.5749$ & $\mathrm{p}=0.1327$ & $\mathrm{p}=0.2321$ \\
\hline & $\begin{array}{c}\mathrm{AC} \\
(+/-)\end{array}$ & $\mathrm{p}=0.3975$ & $p=0.0296$ & $\mathrm{p}=0.1498$ & $\mathrm{p}=0.2021$ & $\mathrm{p}=0.4381$ & $\mathrm{p}=0.1510$ & $p=0.0258$ \\
\hline & $\begin{array}{c}\text { Competitor } \\
\text { x AC }\end{array}$ & $\mathrm{p}=0.3508$ & $\mathrm{p}=0.4042$ & $\mathrm{p}=0.8392$ & $\mathrm{p}=0.9254$ & $\mathrm{p}=0.3004$ & $\mathrm{p}=0.9821$ & $\mathrm{p}=0.3792$ \\
\hline \multirow{3}{*}{ Competitor } & $\begin{array}{l}\text { Competitor } \\
\text { ID }\end{array}$ & $\mathrm{p}=0.9575$ & $\mathrm{p}=0.7938$ & $\mathrm{p}=0.4264$ & $\mathrm{p}=0.6925$ & $\mathrm{p}=0.7659$ & $\mathrm{p}=0.5884$ & $\mathrm{p}=0.2321$ \\
\hline & $\begin{array}{l}\mathrm{AC} \\
(+/-)\end{array}$ & $p=0.0040$ & $\mathrm{p}=0.1181$ & $p=0.0056$ & $p=0.0380$ & $\mathrm{p}=0.7407$ & $p=0.0192$ & $p=0.0258$ \\
\hline & $\begin{array}{c}\text { Competitor } \\
\text { ID x AC }\end{array}$ & $p=0.0369$ & $\mathrm{p}=0.5701$ & $p=0.0859$ & $\mathrm{p}=0.2676$ & $\mathrm{p}=0.3814$ & $\mathrm{p}=0.1935$ & $\mathrm{p}=0.5400$ \\
\hline
\end{tabular}


Table 3.2: Summary table of backtransformed least-squared means and $95 \%$ confidence limits for dependent variables for ginseng with a significant AC effect.

\begin{tabular}{|c|c|c|c|c|}
\hline $\begin{array}{c}\text { Study } \\
\text { Component }\end{array}$ & Dependent Variable & $-A C$ & $+A C$ & $\overline{\text { Change }}$ \\
\hline \multirow{5}{*}{$\begin{array}{c}\text { Striped Violet } \\
\text { Effect } \\
\text { (Fig. 3.1a) }\end{array}$} & Root Length (cm) & $\begin{array}{c}9.006 \\
(8.1451,9.9580)\end{array}$ & $\begin{array}{c}11.2425 \\
(10.2052,12.3852) \\
\end{array}$ & $25 \%$ \\
\hline & Shoot Mass (g) & $\begin{array}{c}0.0519 \\
(0.0441,0.0645)\end{array}$ & $\begin{array}{c}0.0750 \\
(0.0645,0.0870)\end{array}$ & $45 \%$ \\
\hline & Root Mass (g) & $\begin{array}{c}0.0947 \\
(0.0792,0.1132)\end{array}$ & $\begin{array}{c}0.1319 \\
(0.1110,0.0871)\end{array}$ & $39 \%$ \\
\hline & Total Biomass (g) & $\begin{array}{c}0.1378 \\
(0.1159,0.1639) \\
\end{array}$ & $\begin{array}{c}0.1875 \\
(0.1578,0.2226)\end{array}$ & $36 \%$ \\
\hline & $\mathrm{RGR}_{\mathrm{LA}}$ & $\begin{array}{c}0.5164 \\
(0.3387,0.6940) \\
\end{array}$ & $\begin{array}{c}0.8637 \\
(0.6807,1.047) \\
\end{array}$ & $67 \%$ \\
\hline \multirow{2}{*}{$\begin{array}{c}\text { Garlic Mustard } \\
\text { Effect } \\
\text { (Fig. 3.1b) }\end{array}$} & Root Length (cm) & $\begin{array}{c}9.3924 \\
(8.3822,10.5243) \\
\end{array}$ & $\begin{array}{c}11.0685 \\
(10.0467,12.1941) \\
\end{array}$ & $18 \%$ \\
\hline & $\mathrm{RGR}_{\mathrm{LA}}$ & $\begin{array}{c}0.4985 \\
(0.3249,0.6940)\end{array}$ & $\begin{array}{c}0.7454 \\
(0.5911,0.8996)\end{array}$ & $50 \%$ \\
\hline \multirow{3}{*}{$\begin{array}{c}\text { Competitor Identity } \\
\text { (Fig. 3.1c) }\end{array}$} & Root Mass (g) & $\begin{array}{c}0.1123 \\
(0.0882,0.1429)\end{array}$ & $\begin{array}{c}0.1524 \\
(0.1258,0.1847) \\
\end{array}$ & $36 \%$ \\
\hline & Total Biomass (g) & $\begin{array}{c}0.1572 \\
(0.1244,0.1988)\end{array}$ & $\begin{array}{c}0.2252 \\
(0.1854,0.2735)\end{array}$ & $43 \%$ \\
\hline & $\mathrm{RGR}_{\mathrm{LA}}$ & $\begin{array}{c}0.5885 \\
(0.3909,0.7851) \\
\end{array}$ & $\begin{array}{c}0.8830 \\
(0.7095,1.056) \\
\end{array}$ & $50 \%$ \\
\hline
\end{tabular}




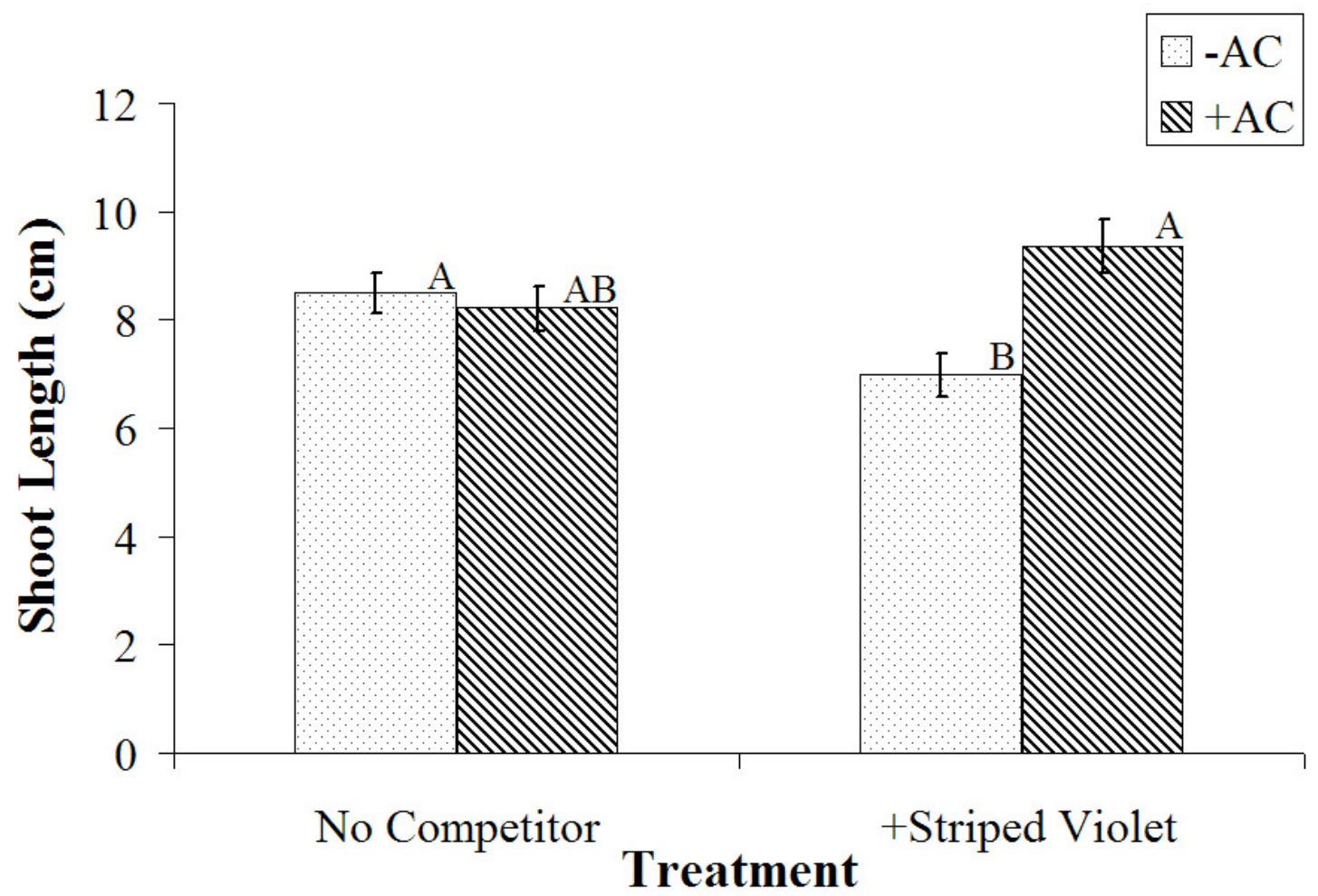

Figure 3.3 Differential effect of striped violet on mean shoot length $(\mathrm{cm})$ depended on AC treatment. 
with or without $\mathrm{AC}$ in the soil (competitor main effect; $\mathrm{F}=23.13, \mathrm{p}<0.0001$ ), an effect comparable to that seen with native violet. In 2007 , there was also a trend suggesting a greater effect of garlic mustard on ginseng mortality in the absence of AC (competitor * $\mathrm{AC}$ interaction; $\mathrm{L}-\mathrm{R} \chi^{2}=2.91, \mathrm{p}=0.0859$; Fig. $3.2 \mathrm{~b}$ ). There was also a tendency for ginseng leaf number to increase in the absence of garlic mustard regardless of AC presence (garlic mustard main effect; $\mathrm{L}-\mathrm{R} \chi^{2}=2.72, \mathrm{p}=0.0988$ ). Shoot length, shoot mass, root mass, total biomass and root:shoot ratio of ginseng were not significantly affected by AC, garlic mustard, or by non-additive effects of the two (Table 3.1). However, as before, there was an increase in ginseng root length $(18 \%)$ and the relative growth rate of leaf area $(50 \%)$ in the presence of $\mathrm{AC}$ (Table 3.1,3.2). Moreover, there was no dependency of this $\mathrm{AC}$ effect on presence of garlic mustard.

\section{Competition Treatments}

When analyzing only the competition treatments (Fig. 3.1c), we see similar trends in the data. In 2006 and 2007, ginseng mortality was not significantly affected by the competitor's identity or presence of AC. However, there was a trend for ginseng leaf number to increase in the presence of $\mathrm{AC}$ regardless of competitor identity (AC main effect; $\mathrm{L}-\mathrm{R} \chi^{2}=2.95, \mathrm{p}=0.0857$ ). The two competitor species were very similar in their effects on ginseng growth variables (Table 3.1). Root length and root:shoot ratio were not significantly affected by AC presence or the competitor identity (Table 3.1). Nevertheless, as in the other analyses, AC stimulated ginseng root mass (36\%), total biomass $(43 \%)$ and the relative growth rate of leaves (50\%) regardless of competitor identity (AC main effect; Table 3.1,3.2). The effect of AC on ginseng shoot length differed for the two species (competitor * AC interaction; $\mathrm{F}=4.41, \mathrm{p}=0.0390$ ); there was 

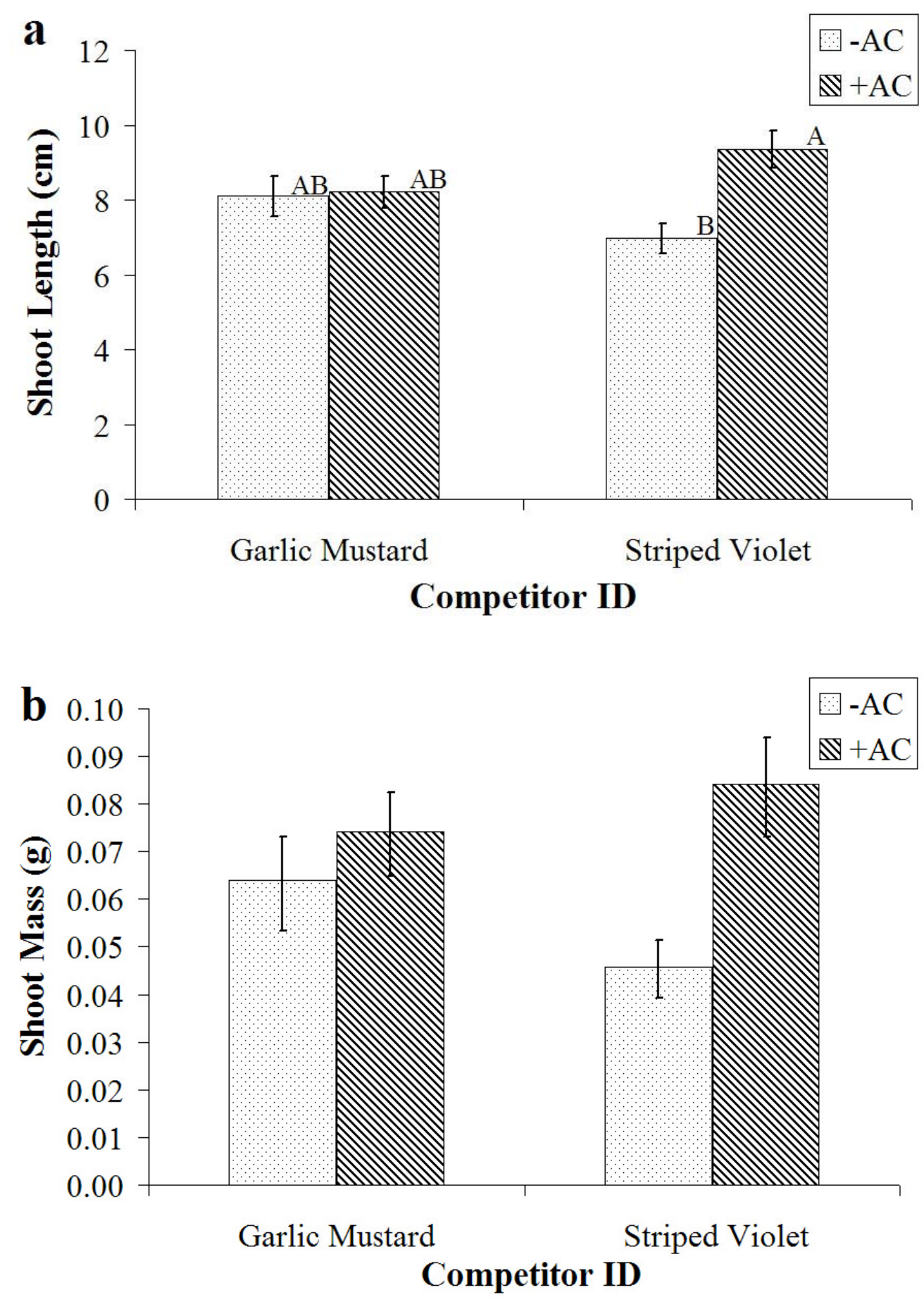

Figure 3.4: (a) Differential effect of competitor species on mean shoot length $(\mathrm{cm})$ in ginseng seedlings after two growing seasons depending on AC treatment; means with the same letter are not significantly different using the Tukey-Kramer HSD a posteriori test, and (b) effect of activated carbon presence and competitor identity on mean shoot mass in ginseng seedlings after two growing seasons $(0.05<\mathrm{p}<0.10)$; no post hoc test was performed since the interactive effect was only a trend. 


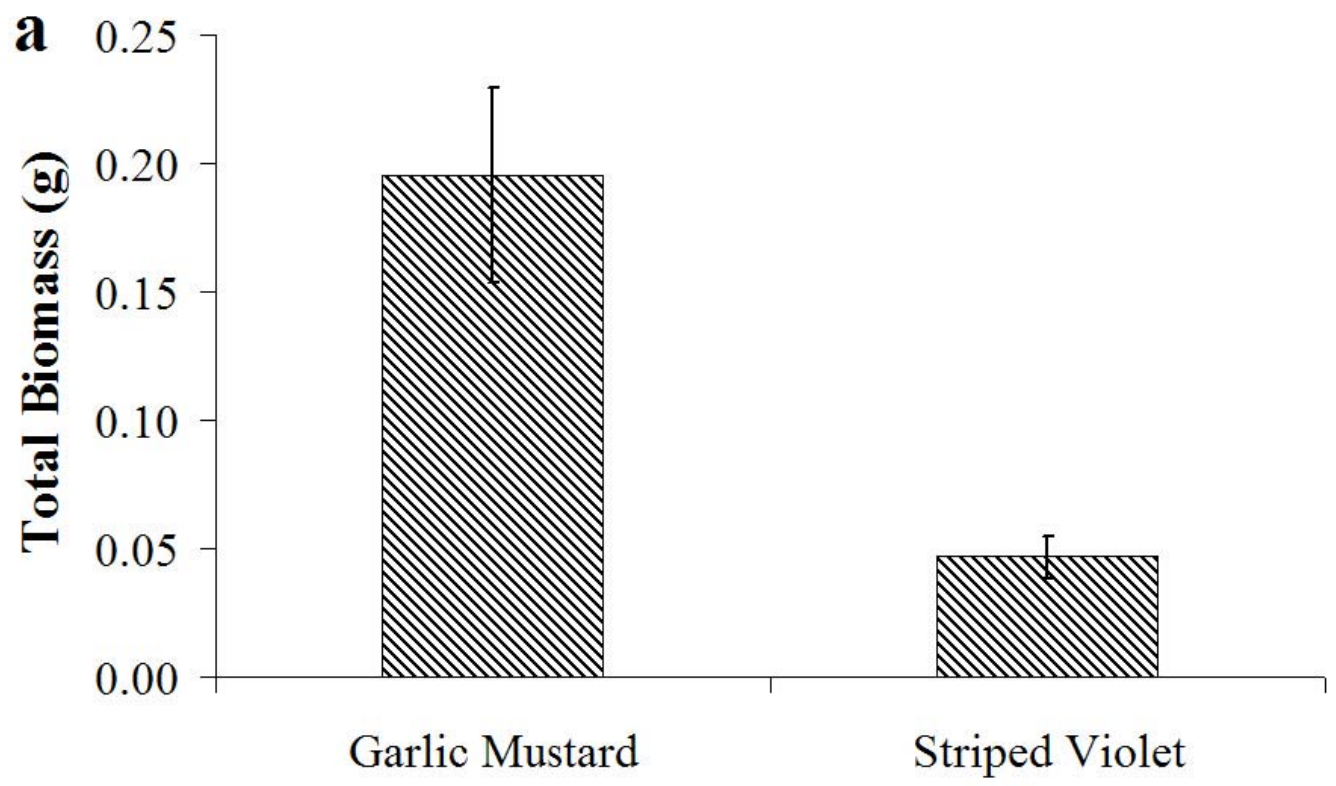

Species

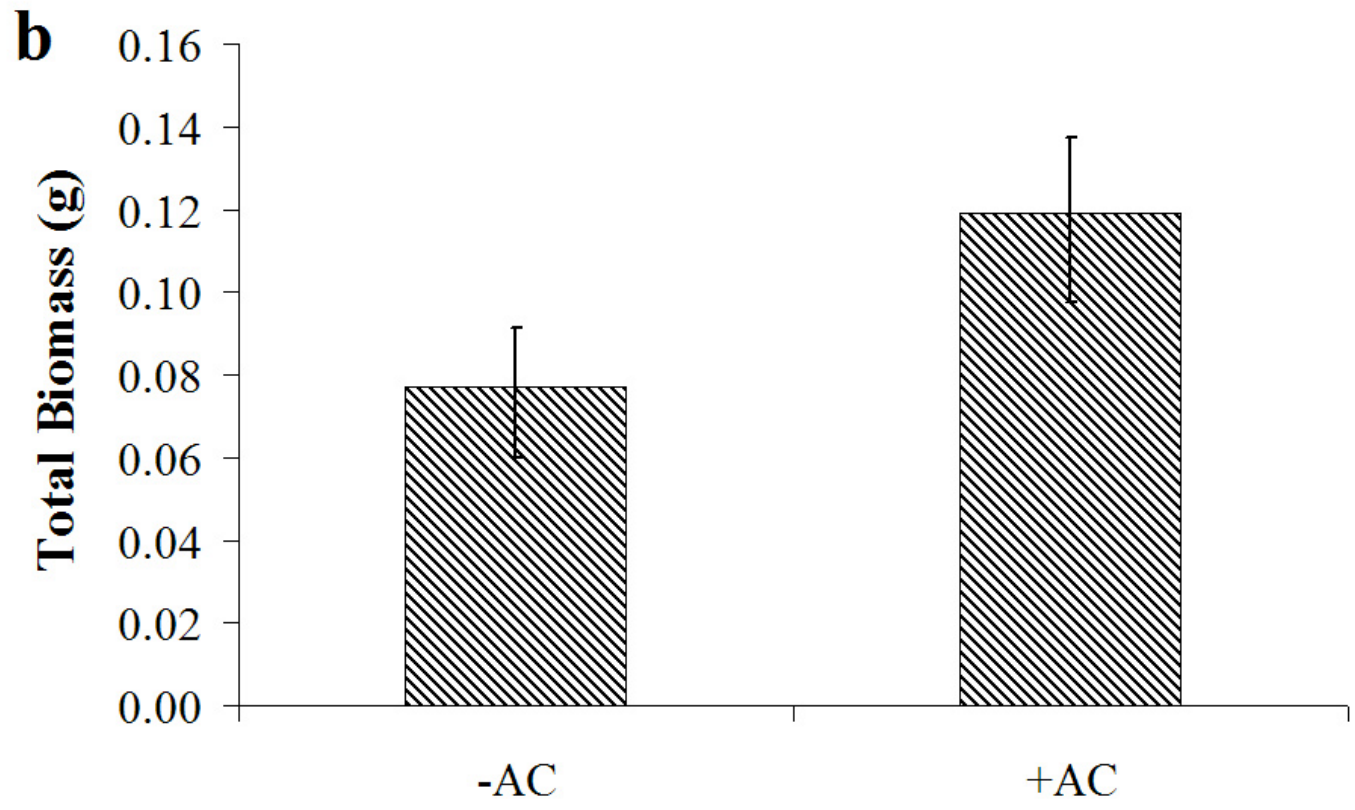

Treatment

Figure 3.5: (a) Competitor biomass after two growing seasons and (b) effect of AC treatment on biomass of the competitor after two growing seasons 
no effect of $\mathrm{AC}$ when the competitor was garlic mustard, but $\mathrm{AC}$ addition enhanced shoot length when ginseng competed with violet (Fig. 3.4a). The same pattern was observed for shoot mass (competitor * AC interaction; $\mathrm{F}=3.03, \mathrm{p}=0.0859$; Fig. 3.4b).

The biomass of garlic mustard was significantly higher than that of striped violet, regardless of $\mathrm{AC}$ presence or absence (Species effect; $\mathrm{F}=29.93$, $\mathrm{p}=0.0001$; Fig. 3.5a). There was also a trend suggesting $\mathrm{AC}$ treatment stimulated competitor biomass (AC main effect; $F=2.80, \mathrm{p}=0.0985 ;$ Fig. 3.5b).

In the striped violet treatments, ginseng biomass was not significantly affected by $\mathrm{AC}$ or variation in striped violet biomass ( $\mathrm{p}>0.05$ for all model effects). However, within the garlic mustard treatments, ginseng biomass increased as garlic mustard biomass increased (competitor biomass effect; $\mathrm{F}=15.36, \mathrm{p}=0.0050$ ). This effect did not depend on carbon treatment (competitor biomass * AC; $\mathrm{p}>0.05$ ). When examining the competition treatments, ginseng biomass was found to increase as competitor biomass increased (competitor biomass effect; $\mathrm{F}=8.71, \mathrm{p}=0.0045$ ), yet this effect did not depend on carbon treatment or competitor identity (competitor biomass * AC interaction; $\mathrm{p}>0.05$ ).

\section{DISCUSSION}

In the presence of a competitor, ginseng seedling mortality increased, and this effect was comparable in magnitude for the native and invasive competitor. However, within garlic mustard treatments there was a tendency for this mortality effect of garlic mustard to be less in the presence of activated carbon. While reduced resource availability likely increased ginseng seedling mortality within competition treatments, the differential response of ginseng to carbon treatment in the presence of garlic mustard is consistent with an allelopathic effect as well. Ginseng survival was $21 \%$ higher in garlic 
mustard treatments that contained AC in the soils than in soil without AC. As with most plants, the early establishment phase of seedlings is critical. An increase in seedling mortality may be particularly important for future recruitment within invaded ginseng populations.

The effect of striped violet on ginseng shoot length depended on AC treatment with ginseng shoot length significantly increasing in striped violet treatments with AC. This differential response may be explained by two possible causes: allelopathy or resource competition. Until the work by Lau et al. (2008) and our results showing positive effects of activated carbon, we would have concluded that the native striped violet was allelopathic despite its tendency to co-occur with American ginseng. However, AC may have altered the degree of competition for nutrients. Competition with neighbors has been well documented to affect survival and growth (Aarssen and Epp 1990), and plants with similar niches may be stronger competitors (Goldberg and Werner 1983). Striped violet and ginseng may have been strong competitors which may be the reason why stems of ginseng seedlings were longer, even as the competitor biomass increased in carbon treatments. Furthermore, if AC altered limiting soil nutrients, then the competitive effect of violet through resource depletion may have been reduced as well.

The lack of allelopathic effects of garlic mustard on ginseng seedling growth may be due to a variety of factors. Our study simulated a newly invaded area with a low density of garlic mustard. However, earlier studies have found that garlic mustard grows better in previously invaded sites (Klironomos 2002). In addition, increased $\mathrm{N}$ and $\mathrm{P}$ availability, soil $\mathrm{pH}$ and base cation availability were associated with field populations of garlic mustard (Rodgers et al. 2008). These nutrient effects could be cumulative over 
time, creating a beneficial feedback for garlic mustard but not for native species. In addition, Vaughn and Berhow (1999) found that glucosinolate concentrations in garlic mustard were highest in the fall, potentially indicating that decomposition of garlic mustard would produce the most inhibitory effect. In our study, we removed garlic mustard before it had a chance to decompose in order to measure its biomass. Furthermore, garlic mustard seeds have been found to contain high levels of sinigrin, a phytotoxic glycoside (Larsen et al. 1983). It is possible that the combined effects of compounds leaching from seeds and adult decomposition alter soils over time to benefit further invasion and prevent native growth. Additionally, while garlic mustard has been found to allelopathically reduce growth in species like Geum laciniatum (Prati and Bossdorf 2004), such effects may be species specific (Meekins and McCarthy 1999).

The lack of competitive effects of garlic mustard on ginseng seedling growth is also interesting. Overall, garlic mustard was a large competitor that many times grew taller than and shaded the ginseng seedlings. Meekins and McCarthy (1999) found species' specific effects of garlic mustard rosettes on native plants such as chestnut oak (Quercus prinus), box elder (Acer negundo) and spotted jewelweed (Impatiens capensis). In that study, garlic mustard was outcompeted by the latter two species; however, garlic mustard was able to reduce the growth of chestnut oak (Meekins and McCarthy 1999). The researchers attributed chestnut oak's reduced biomass in the presence of garlic mustard to light competition. However, ginseng is a shade-obligate species and growth was not significantly affected by resource competition from garlic mustard in our study.

The presence of activated carbon in the soil affected several ginseng growth variables, regardless of competitor presence or identity. The recent study by Lau et al. 
(2008) found that addition of activated carbon in unfertilized soils significantly increased $\mathrm{pH}$, phosphorus, potassium and iron concentrations in soil leachates, whereas calcium and magnesium decreased. While the study by Lau et al. (2008) was conducted over a single week, it showed immediate effects of activated carbon that could persist over a longer time frame. Lau et al. (2008) also conducted three growth experiments in which they added activated carbon to potting media and found that in most herbaceous species, activated carbon presence increased biomass. The increase in biomass was attributed to changes in nutrient availability. A similar phenomenon may have been responsible for increased ginseng growth in AC treatments in our study.

In addition to activated carbon's effects on soil nutrients, two other factors may explain our results. First, inhibitory organic compounds already found in the soil at the study area and our treatment design may have resulted in enhanced growth as activated carbon removed the compounds from the rhizosphere. Bracken and interrupted ferns existed in parts of the study area, and caution was taken to avoid planting treatments directly in fern patches since previous studies have demonstrated allelopathy in ferns (Stewart 1974: Hanson and Dixon 1986). However, by the end of the second year, some ferns had encroached near treatments. Second, our treatments also required mixing of the soils as well as removal of other herbaceous species which created more control over our experimental design but deviated from natural conditions. For example, Booth et al. (2006) found that mixed soil cores had higher mineralization and $\mathrm{NH}_{4}{ }^{+}$assimilation, while $\mathrm{NO}_{3}{ }^{-}$consumption declined.

Overall, our results do show a surprising effect of activated carbon on both ginseng and biomass of the competitor species. These results reaffirm the need for a 
better understanding of how activated carbon alters soil nutrients, especially over time. Our results from this field study parallel greenhouse experiments conducted by Lau et al. (2008) which suggest that activated carbon treatments may confound test species' growth and bias allelopathy assumptions. Ginseng mortality increased with the addition of a competitor, and trends in the data suggest that ginseng survival in the presence of garlic mustard depended on carbon treatment, suggestive of allelopathy. The lack of competitive effects of either competitor on ginseng growth may indicate ginseng seedling resilience to low levels of competition; however, reduced recruitment of ginseng seedlings via increased mortality may be sufficient to significantly lower population growth rates in invaded populations. 


\section{REFERENCES}

Aarssen LW, Epp GA (1990) Neighbour manipulations in natural vegetation: a review. J of Veg Sci 1(1):13-30.

Anderson, RC, Fralish JS, Armstrong JE, Benjamin PK (1993) The ecology and biology of Panax quinquefolium L. (Araliaceae) in Illinois. Am Midl Nat 129:357-372.

Anderson RC, Dhillion SS, Kelley TM (1996) Aspects of the ecology of an invasive plant, garlic mustard (Alliaria petiolata), in central Illinois. Restor Ecol 4(2):181-191.

Bailey B (1999) Social and economic impacts of wild harvested products. Ph.D. Dissertation, West Virginia University, Morgantown, WV.

Bais HP, Vepachedu R, Gilroy S, Callaway RM, Vivanco JM (2003) Allelopathy and exotic plant invasion: from molecules and genes to species interactions. Science 301(5):1377-1380.

Booth MS, Stark JM, Hart SC (2006) Soil mixing effects on inorganic nitrogen production and consumption in forest and shrubland soils. Plant Soil 289:5-15.

Butcko VM, Jensen RJ (2002) Evidence of Tissue-specific allelopathic activity in Euthamia graminifolia and Solidago canadensis (Asteraceae) Am Midl Nat 148(2): 253-262.

Callaway RM, Aschehoug ET (2000) Invasive plants versus their new and old neighbors: a mechanism for exotic invasion. Science 290:521-523.

Callaway RM, Ridenour WM (2004) Novel weapons: invasive success and the evolution of increased competitive ability. Front Ecol 2(8):436-443.

Callaway RM, Cipollini D, Barto K, Thelen GC, Hallett SG, Prati D, Stinson K Klironomos J (2008) Novel weapons: Invasive plant suppresses fungal mutualists in America but not in its native Europe. Ecology 89(4):1043-1055.

Cavers PB, Heagy MI, Kokron RF (1979) The biology of Canadian weeds. 35. Alliaria petiolata (M. Bieb) Cavara and Grande. Can J of Plant Science 59:217-229.

Charron D, Gagnon D (1991) The demography of northern populations of Panax quinquefolium (American ginseng). J Ecol 79(2):431-445. 
Cheremisinoff PN, Morresi AC (1978) Carbon adsorption applications. In:

Cheremisinoff PN, Ellerbusch F, eds. Carbon adsorption handbook. Ann Arbor, MI, USA: Science Publishers, Inc., 1-53.

Cipollini D (2002) Variation in the expression of chemical defenses in Alliaria petiolata (Brassicaceae) in the field and common garden. Am J Bot 89(9): 1422-1430.

Cipollini D, Mbagwu J, Barto K, Hillstrom C, Enright S (2005) Expression of constitutive and inducible chemical defenses in native and invasive populations of Alliaria petiolata. J Chem Ecol 31:1255-1267.

Cipollini D, Gruner B (2007) Cyanide in the chemical arsenal of garlic mustard, Alliaria petiolata. J Chem Ecol 33:85-94.

Cipollini KA, McClain GA, Cipollini D (2008) Separating above-and belowground effects of Alliaria petiolata and Lonicera maackii on the performance of Impatiens capensis Am Midl Nat 160:117-128.

Cruse-Sanders JM, Hamrick JL (2004) Spatial and genetic structure within populations of wild American ginseng (Panax quinquefolius L. Araliaceae). $\mathrm{J}$ of Hered 95(4):309-321.

D'Antonio CM, Vitousek PM (1992) Biological invasions by exotic grasses, the grass/fire cycle, and global change. Ann Rev Ecology Systematics 23: $63-87$.

Ehrenfeld JG, Scott NS (2001) Invasive species and the soil: effects on organisms and ecosystem processes. Ecol Appl 11(5): 1259-1260.

Goldberg DE, Werner P (1983) Equivalence of competitors in plant communities: a null hypothesis and a field experimental approach. Am J Bot 70: 1098 - 1104.

Gomez-Aparicio L, Canham CD (2008) Neighbourhood analyses of the allelopathic effects of the invasive tree Ailanthus altissima in temperate forests. J Ecol 96(3): 447-458.

Hackney EE, McGraw JB (2001) Experimental demonstration of an allee effect in American ginseng. Conserv Biol 15:129-136

Hanson PJ, Dixon RK (1986) Allelopathic effects of interrupted fern on northern red oak seedlings: Amelioration by Suillus luteus L.: Fr. Plant and Soil 98(1): 4351.

Heisey RM (1990) Allelopathic and herbicidal effects of extracts from Tree of Heaven (Ailanthus altissima). Am J of Bot 77(5): 662-670. 
Heisey RM (1996) Identification of an allelopathic compound from Ailanthus altissima (Simaroubaceae) and characterization of its herbicidal activity. Am J Bot 83(2):192-200.

Inderjit, Callaway RM (2003) Experimental designs for the study of allelopathy. Plant and Soil 256:1-11.

Inderjit, Weston LA (2000) Are laboratory bioassays for allelopathy suitable for prediction of field responses? J Chem Ecol 26(3):2111-2118.

Klironomos JN (2002) Feedback with soil biota contributes to plant rarity and invasiveness in communities. Nature 417:67-70.

Kulmatiski A, Beard KH (2005) Activated carbon as a restoration tool: potential for control of invasive plants in abandoned agricultural fields. Restor Ecology 14(2): 251-257.

Larsen LM, Olsen O, Plöger A, Sorenson H (1983) Sinapine-O- -Dglucopyranoside in seeds of Alliaria officinalis. Phytochemistry 22:219-222.

Lau JA, Puliafico KP, Kopshever JA, Steltzer H, Jarvis EP, Schwarzländer M, Strauss SY, Hufbauer RA (2008) Inference of allelopathy is complicated by effects of activated carbon on plant growth. New Phytologist 178 (2):412-423.

Lewis WH, Zenger VE (1982) Population dynamics of the American ginseng Panax quinquefolium (Araliaceae). Am J Bot 69:1483-1490.

McCarthy B (1997) Response of a forest understory community to experimental removal of an invasive nonindigenous plant (Alliaria petiolata, Brassicaceae). In: Luken JO, Thieret JW (eds). Assessment and management of plant invasions. Springer-Verlag. New York. pp 117-130

McCarthy B, Hanson SH (1998) An assessment of allelopathic potential of the invasive weed Alliaria petiolata (Brassicaceae). Castanea 63(1):68-73.

McGraw JB, Garbutt K (1990) Demographic growth analysis. Ecology 71(3): 1199-2004.

McGraw JB, Sanders SM, Van der Voort ME (2003) Distribution and abundance of Hydrastis canadensis L. (Ranunculaceae) and Panax quinquefolius L. (Araliaceae) in the central Appalachian region. J Torrey Bot Soc 130(2):62-69.

McGraw JB, Furedi MA (2005) Deer browsing and population viability of a forest understory plant. Science 307:920-922. 
Meekins JF, McCarthy BC (1999) Competitive ability of Alliaria petiolata (Garlic mustard, Brassicaceae), an invasive, nonindigenous forest herb. Inter J Plant Sci 160(4):743-752.

Mooney EH, McGraw JB (2007) Alteration of selection regime resulting from harvest of American ginseng, Panax quinquefolius. Conserv Genet 8:5767.

Nagel JM, Griffin KL (2004) Can gas-exchange characteristics help explain the invasive success of Lythrum salicaria? Biological Invasions 6:101-111.

Nilsson MC (1994) Separation of allelopathy and resource competition by the boreal dwarf shrub Empetrum hermaphroditum Hagerup. Oecologia 98(1):1-7.

Nilsson MC, Zackrisson O (1992) Inhibition of Scots pine seedling establishment by Empetrum hermaphroditum. J Chem Ecol 18(10): 1857-1870.

Nilsson MC, Zackrisson O, Sterner O, Wallstedt O (2000) Characterisation of the differential interference effects of two boreal dwarf shrub species. Oecologia 123(1): 122-128.

Nuzzo V (1993) Distribution and spread of the invasive biennial garlic mustard (Alliaria petiolata) in North America. In: McKnight BN (ed.) Biological pollution: the control and impact of invasive exotic species. Indiana Academy of Science, Indianapolis. pp 137-146.

Nuzzo V (1999) Invasion pattern of the herb garlic mustard (Alliaria petiolata) in high quality forests. Biol Invasions 1:169-179.

Nuzzo V (2000) Element stewardship abstract for Alliaria petiolata Garlic mustard. Nature Conservancy 1-19.

Prati D, Bossdorf O (2004) Allelopathic inhibition of germination by Alliaria petiolata (Brassicaceae). Am J Bot 91(2):285-288.

Rasband WS (2005) ImageJ; v1.37, U. S. National Institutes of Health, Bethesda, Maryland, USA, http://rsb.info.nih.gov/ij/.

Rice EL (1984) Allelopathy. Academic Press Inc. The University of Okalahoma. Norman Oklahoma

Rich EL (2004) Investigation of allelopathy in invasive introduced tree species, Norway maple (Acer platanoides L.). PhD Dissertation. Drexel University, PA. 
Ridenour WM, Callaway RM (2001) The relative importance of allelopathy in interference: the effects of an invasive weed on a native bunchgrass. Oecologia $126: 444-450$.

Robbins CS (2000) Comparative analysis of management regimes and medicinal plant trade monitoring mechanisms for American ginseng and goldenseal. Conserv Biol 1422-1434.

Roberts KJ, Anderson RC (2001) Effect of garlic mustard [Alliaria petiolata (Beib. Cavara \& Grande)] extracts on plants and arbuscular mycorrhizal (AM) fungi. Am Midl Nat 146:146-152.

Rodgers VL, Wolfe BE, Werden LK, Finzi AC (2008) The invasive species Alliaria petiolata (garlic mustard) increases soil nutrient availability in northern hardwood-conifer forests. Oecologia 157:459-471.

Seo H, Anderson RC (1990) Effect of soil microbial and mycorrhizal associations on the productivity and photosynthetic rates of Panax quinquefolium L. Myco Soc Am Newsl 41:4.

Schmidt SK (1988) Degradation of juglone by soil bacteria. J Chem Ecol 14:1561--1571.

Shahi DP (2007) Effects of density on reproduction and demographic structures of American ginseng (Panax quinquefolius) populations in Ohio. $\mathrm{PhD}$ dissertation.

Soil Survey Staff (2008) National Soil Survey Characterization Data. Soil Survey Laboratory. National Soil Survey Center. USDA-NRCS - Lincoln, NE.

Stewart RE (2005) Allelopathic potential of western bracken. J Chem Ecol 1(2): 161169.

Stinson KA, Campbell SA, Powell JR, Wolfe BE, Callaway RM, Thelen GC, Hallett SG, Prati D, Klironomos JN (2006) Invasive plant suppresses the growth of native tree seedlings by disrupting belowground mutualisms. PLoS Biol 4(5): 0727-0731.

Stinson K, Kaufman S, Durbin L, Lowenstein F (2007) Impacts of garlic mustard invasion on a forest understory community. Northeast Nat 14(10):73-88.

Strausbaugh PD, Core EL (1978) Flora of West Virginia, $2^{\text {nd }}$ edition. Seneca books, Morgantown, WV. 1079 pp.

Thomson D (2005) Measuring the effects of invasive species on the demography of a rare endemic plant. Biol Invasions 7:615-624. 
United States Department of Agriculture, Natural Resources Conservation Service (2008) The PLANTS Database (http://plants.usda.gov, 09 September 2008). National Plant Data Center, Baton Rouge, LA 70874-4490 USA

Van der Voort ME, McGraw JB (2006) Effects of harvester behavior on population growth rate affects sustainability of ginseng trade. Biol Conserv 130(4): 505-516.

Vaughn SF, Berhow MA (1999) Allelochemicals isolated from tissues of the invasive weed garlic mustard (Alliaria petiolata). J Chem Ecol 25(11):2495-2504.

Vitousek PM, WalkerLR, Whiteaker LD, Mueller-Dombois D, Watson PA (1987) Biological invasion by Myrica faya alters ecosystem development in Hawaii. Science 238(4828): 802-804.

Wardle DA, Nilsson MC, Gallet C, Zackrisson O (1998) An ecosystem-level perspective of allelopathy. Biol Rev 73:305-319.

Weber JS, Gibson KD (2007) Exotic plant species in old-growth forest in Indiana. Weed Sci 55:299-304.

Welk E, Schubert K, Hoffmann MH (2002) Present and potential distribution of invasive garlic mustard (Alliaria petiolata) in North America. Diversity Distrib 8:219-233.

Wixted K, McGraw JB (2008) A Panax-centric view of invasive species. Biol Invasions. doi: 10.1007/s10530-008-9301-7.

Wolfe BE, Rodgers VL, Stinson KA, Pringle A (2008) The invasive plant Alliaria petiolata (garlic mustard) inhibits ectomycorrhizal fungi in its introduced range. J Ecol 96(4): 777-783.

\section{ACKNOWLEDGMENTS}

Funding for this project was provided by NSF grant DEB-0613611 to J. B. McGraw. We also would like to thank numerous people who contributed to this project especially- Bob Beyfuss, Alyssa Hanna, Adam Martin, David Kazyak, Emily Mooney, Chris Huffman and Jerry Baird as well as landowners for the use of the research site. 


\section{Chapter IV:}

EFFECTS OF GARLIC MUSTARD (ALLIARIA PETIOLATA) DENSITY AND LEAF LITTER ADDITION ON AMERICAN GINSENG (PANAX QUINQUEFOLIUS) GROWTH AND REPRODUCTION 


\begin{abstract}
As the invasive garlic mustard (Alliaria petiolata) colonizes new areas, there is a need to understand how this species may interact with native species. Accordingly, we examined growth and reproduction of a valuable understory herb, American ginseng (Panax quinquefolius L.), under manipulated densities of garlic mustard. Furthermore, we examined how addition of garlic mustard leaf litter may affect ginseng growth and reproduction. Despite extreme garlic mustard treatments, we found no significant effect of garlic mustard density or leaf litter addition on ginseng growth variables. However, two reproductive variables, the proportion of flower buds which developed into berries as well as the number of seeds per flower bud tended to decrease as weight of garlic mustard leaf litter increased. This finding shows that under higher densities of garlic mustard, ginseng seed production may decline, ultimately affecting fecundity.
\end{abstract}

Keywords: American ginseng, Panax quinquefolius, Alliaria petiolata, garlic mustard, invasive species, density 


\section{INTRODUCTION}

Density effects on terrestrial plant populations have been well studied (Antonovics and Levin 1980; Thomas and Weiner 1989; Weiner 1990). Higher plant densities can have several effects, including increased mortality or decreased growth and reproduction per plant (Palmblad 1968; Ford 1975). However, few studies have examined the effect of invasive plant density on native plant survival and growth. As invasive species colonize new areas, early population densities can vary extensively, creating a need to understand how those changes may affect native species. In many cases, invasive species can alter soil attributes which create environments suitable for higher densities of invasives through positive feedbacks (Klironomos 2002; Rodgers et al. 2008).

Currently, garlic mustard (Alliaria petiolata) is invading the eastern North American forests at an alarming rate (Nuzzo 1993), and garlic mustard can colonize in the absence of disturbance. Garlic mustard is a non-mycorrhizal biennial which shows high phenotypic plasticity (Byers and Quinn 1998) allowing it to survive in a variety of habitats from forest edges and floodplains to undisturbed understories and old-growth forests (Nuzzo 1993; Nuzzo 1999; Stinson et al. 2006; Weber and Gibson 2007). Its rapid growth (Cavers et al. 1979) and ability to produce large numbers of small, dormant seeds (Trimbur 1973, Baskin and Baskin 1992) allow garlic mustard stands to proliferate.

In contrast to the invasive garlic mustard, American ginseng is an important mycorrhizal, herbaceous species found throughout the eastern United States (Seo and Anderson 1990; Bailey 1999; Robbins 2000; McGraw et al. 2003). Ginseng is a long- 
lived perennial species that is widely harvested for its valuable root; however its populations are currently threatened by deer browsing (McGraw and Furedi 2005), poor harvest practices (Van der Voort and McGraw 2006) and inbreeding along with reduced genetic diversity (Cruse-Sanders and Hamrick 2004, Mooney and McGraw 2007).

Wixted and McGraw (2008) found garlic mustard invasion in 5 of 30 natural ginseng populations with as many as $7.1 \%$ of the 4,279 ginseng plants monitored having garlic mustard within a $2 \mathrm{~m}$ radius. The effects of garlic mustard density on ginseng, however, are unknown.

Currently, resource competition and allelopathy are believed to be essential for garlic mustard's success (Meekins and McCarthy 1999; Vaughn and Berhow 1999; Prati and Bossdorf 2004; Stinson et al. 2006). Several secondary compounds have been isolated from garlic mustard tissues including glucosinolates and cyanide (Vaughn and Berhow 1999; Cipollini and Gruner 2007). Glucosinolate degradation in the soil has been found to release isothiocyanates and nitrile (Brown et al. 1994), and certain forms of isothiocyanates have been found to inhibit germination of mycorrhizal fungi (Shreiner and Koide 1993a,b). This degradation product may be the reason why soils previously invaded by garlic mustard contain significantly less mycorrhizal fungi (Stinson et al. 2006). Furthermore, garlic mustard has been found to alter soil nutrients (Rodgers et al. 2008), creating a positive feedback for the invasive (Klironomos 2002). Changes in both mutualistic symbioses and nutrients could have community-level impacts, especially within deciduous forests in the United States whose species rely heavily on mycorrhizal associations (Smith and Read 1997). 
A recent study found that garlic mustard did not competitively or allelopathically affect ginseng seedling growth, though there was evidence that garlic mustard allelopathically increased ginseng mortality (Wixted and McGraw, unpublished data). The previous experiment, however, tested a single, low density of garlic mustard on ginseng seedlings and did not allow the garlic mustard to decompose on the site. Given that degradation of glucosinolates produces phytotoxic chemicals, degradation of garlic mustard leaf litter may play a role in its success as an invader. Furthermore, Stinson et al. (2007) found a negative correlation between diversity of native plant species and abundance of garlic mustard, suggesting density dependent effects.

Due to garlic mustard's presence within natural ginseng populations (Wixted and McGraw 2008) and the lack of information on how it may affect those populations, our research sought to examine how density and addition of garlic mustard leaf litter may affect ginseng. The objectives of this study were to examine the following questions: 1) Is there evidence for a density effect of garlic mustard on adult ginseng survival, growth and reproduction? 2) Is there evidence for an effect of garlic mustard leaf litter addition on adult ginseng survival, growth and reproduction?

\section{METHODS}

\section{Effects of garlic mustard density}

In October 2007, 3-5yr old ginseng rootlets were obtained from a local grower, and fresh root mass was recorded as an initial size covariate. All roots then were transplanted to a field location near Morgantown, WV. The site contained a mixedmesophytic canopy and a natural population of ginseng. Four $20 \mathrm{~m}^{2}$ blocks were set up within the study area, and 60 plants ( 3 density treatments $\times 20$ replicates/treatment) were 
randomly placed in each block for a total of 240 plants. Treatments had either 0,2 or 4 garlic mustard rosettes planted within $6 \mathrm{~cm}$ of each ginseng rootlet. First year garlic mustard rosettes were collected on site, but no garlic mustard was found within the experimental blocks during setup. Due to high rates of garlic mustard mortality during transplanting, garlic mustard seedlings were transplanted 2 weeks prior to ginseng rootlets. Any garlic mustard seedlings that died within the first week were replaced immediately, and plots were monitored every day the following week to ensure garlic mustard survival before ginseng roots were transplanted. Each ginseng plant was given a unique ID and cryptically tagged with an engraved aluminum nail. At the start of the experiment and every 2 weeks during the growing season (late April-late August), herbaceous plants were removed within a 0.30 m radius of each study plant to prevent potential confounding competitive influences.

In late April 2008, wire-mesh cages were placed over emerging ginseng to exclude large herbivores such as white-tailed deer. Garlic mustard survival was recorded at the beginning of May. Upon full expansion of ginseng leaves in early June, leaf area data were collected using a non-destructive method. In this process, digital images of ginseng leaves were taken and processed in ImageJ v.1.37 (Rasband 2005). Shadows were removed from images, as needed, using Adobe Photoshop v.7.0. Also in early June, data on the number of buds for all reproductive ginseng were collected. At this time, height and leaf number for each garlic mustard treatment were combined and recorded. In early August, data on the number of berries and seeds were collected for reproductive ginseng. The proportion of buds that became berries and the proportion of buds which became seeds were calculated as reproductive fitness components. 
At the end of August 2008, all remaining ginseng plants were harvested. If shoot tissue was not present for ginseng, the area was searched for any roots still present. Ginseng rhizomes which still contained an intact apical bud were considered viable while those without an apical bud were not. Plants lacking shoots at the end of the growing season were excluded from growth analyses. An infection symptomatic of Cylindrocarpon spp. was discovered at this time, so any pieces of remaining ginseng roots were also collected and taken back to the lab. This infection is characterized by a 'rusty' root appearance and eventual root rotting. Many times, foliage remained until later stages of infection.

At the lab, ginseng roots were thoroughly washed to remove excess soil particles and fresh mass was recorded. At this time, roots were classified as uninfected or having either a "low", "medium" or "high" level of infection. Roots which had rusted spots were considered to have "low" infection, while presence of rotted lateral roots was classified as a "medium" infection and rotted taproots were classified as a "high" level of infection. Reproductive structures (including the peduncle) were clipped from the shoot and dried. Root length and shoot length were then recorded before each section was dried. Roots, shoots and reproductive structures were then dried at $65^{\circ} \mathrm{C}$ for $48 \mathrm{hr}$ then weighed. The root:shoot ratio was also calculated to examine if there were allocation differences among the treatments.

\section{Data analysis}

Survival was not analyzed due to uncertainty about whether ginseng plants died due to treatment effects or infection. Due to low survival of garlic mustard over the winter, the original density of garlic mustard placed around the ginseng differed from the 
number which survived until spring. Treatments originally without garlic mustard and those lacking garlic mustard in the spring due to unexpected mortality were not significantly different for ginseng growth variables $(\mathrm{p}>0.05)$. Therefore, the density of garlic mustard in the spring was used as a main effect in the analysis instead of the original treatment. Total leaf number and height of garlic mustard were found to be positively related $(\mathrm{p}<0.05)$, so total leaf number was used as a size covariate for garlic mustard treatments. Ginseng root mass (2007) was found to be positively related to ginseng growth variables and was subsequently used as a covariate for initial size $(p<0.05)$. Due to extensive root damage, ginseng plants with "medium" and "high" infections were excluded from growth and reproductive analyses. Uninfected ginseng plants and those with a "low" infection were not found to be significantly different for ginseng growth and reproductive variables $(\mathrm{p}>0.05)$ and were pooled for analysis. The proportion of buds which became berries as well as the proportion of buds which became seeds could not be calculated due to low sample size.

Two main analyses were performed, one examining all treatments and another examining just garlic mustard treatments. For all treatments, an ANCOVA was used with ginseng root mass (2007) as a covariate and block (nominal) and spring density (continuous) of garlic mustard as the main effects. This analysis was used to examine how density of garlic mustard may affect ginseng growth and reproduction. For the treatments with garlic mustard in the spring, an ANCOVA also was used but with ginseng root mass (2007) as a covariate and block and total number of leaves (continuous) for garlic mustard as main effects. This analysis was used to account for any size variation among garlic mustard treatments while also examining density effects 
on ginseng. In addition, log-likelihood tests were performed to examine if presence or level of infection was related to treatment or garlic mustard size. For all treatments, a log-likelihood analysis was performed with ginseng root mass (2007) as a covariate and block and spring density of garlic mustard as main effects. Within garlic mustard treatments, a log-likelihood analysis was also performed with ginseng root mass (2007) as a covariate and block and garlic mustard size as main effects. If residuals failed to meet the assumption of normality, data were log-transformed, and a Tukey-Kramer post hoc test was used to compare means among levels for significant model effects.

\section{II: Effects of garlic mustard decomposition}

In October 2006, 3-5 yr old ginseng plants were obtained from a local grower, weighed and transplanted to a field location approximately $15 \mathrm{~km}$ from Morgantown, WV. The site contained a mixed-mesophytic canopy dominated by black cherry (Prunus serotina) as well as an adjacent natural population of ginseng. Five $20 \mathrm{~m}^{2}$ blocks were established throughout the site at least $50 \mathrm{~m}$ away from each other to serve as microenvironments. Sixteen ginseng plants were randomly placed in each grid for a total of 80 plants. Ginseng plants were cryptically tagged with engraved aluminum nails and then acclimated to the site prior to application of garlic mustard treatments. Wire-mesh cages were used to exclude large herbivores. The study area did not contain garlic mustard, however invasions were present $<2 \mathrm{~km}$ away.

In May 2008, whole garlic mustard adults were collected from the West Virginia University Core Arboretum. Plants were brought to the lab, roots were thoroughly rinsed to remove soil particles and then plants were separated into groups of four. All siliques were removed to prevent invasion at the study site. Fresh mass of each group was then 
collected, and plants were placed in individually labeled bags. Each group of garlic mustard then was placed in a circular fashion around one ginseng plant and left to decompose. This treatment was designed to maximize the effect of garlic mustard decomposition, simulating an area with a high density of garlic mustard plants. Treatments consisted of ginseng only or ginseng plus decomposing garlic mustard. Two treatments with 8 replicates/treatment block were randomly placed in each grid.

Ginseng leaf area data were collected after full leaf expansion in June 2008 using the same method as the density study. The number of flower buds was counted on each ginseng plant in late June. In early August, the number of berries and seeds were counted. At the end of August, all ginseng plants were harvested. Roots were thoroughly rinsed to remove any soil particles, and then root and shoot portions were separated. Shoot and root lengths as well as fresh root mass were recorded. Reproductive structures were removed. Plant sections were then dried in an oven at $65^{\circ} \mathrm{C}$ for $48 \mathrm{hr}$ then reweighed. The root:shoot ratio was calculated as well as the proportion of buds that developed into berries and the number of seeds per bud. Relative growth rate of roots $\left(\mathrm{RGR}_{\mathrm{RW}}\right)$ was then calculated using equation 1 (McGraw and Garbutt 1990).

Equation 1: $\mathrm{RGR}_{\mathrm{RW}}=\underline{\ln (\operatorname{root} \operatorname{mass} 2008) \_\ln (\operatorname{root} \operatorname{mass} 2006)}$

\section{Data Analysis}

Leaf area (2008) was found to be positively related to ginseng growth variables and was used as a covariate for analysis $(\mathrm{p}<0.05)$. Data were analyzed in two ways. In the first analysis, all treatments were examined using an ANCOVA with block and garlic mustard presence as the main effects and leaf area (2008) as a covariate. This analysis 
was used to determine if the presence of garlic mustard leaf litter had an effect on ginseng growth and reproduction and if that effect depended on the microenvironment (block). In the second analysis, we wanted to examine if the effect of garlic mustard depends on its mass and the environment (block). In this analysis, only garlic mustard treatments were examined with leaf area (2008) as a covariate and garlic mustard mass and block as main effects. Growth and reproductive variables were analyzed with an ANCOVA while the presence of flower buds was analyzed with a log-likelihood test. Survival was not analyzed due to the lack of mortality. If residuals failed to meet the assumption of normality, then data were log-transformed, and a Tukey-Kramer a posteriori test was performed for significant effects.

\section{RESULTS}

\section{Effects of garlic mustard density}

In all treatments and within garlic mustard (GM) treatments, GM density and size had no significant effect on any ginseng growth or reproductive values ( $>0.05)$. In all treatments, block had a significant effect on root length, shoot length, number of flower buds and reproductive mass of ginseng (Table 4.1). Furthermore, block had a tendency to affect leaf area of ginseng in all treatments (Table 4.1). Within GM treatments, block had a significant effect on root length and number of flower buds of ginseng (Table 4.1). In all treatments, block and GM density had no significant effect on presence or level of infection ( $\mathrm{p}>0.05)$. Additionally, within GM treatments, block and GM size had no significant effect on presence or level of infection ( $p>0.05)$. 
Table 4.1: ANOVA summary table of block effects for growth variables and reproductive variables for the density study; significant values $(\mathrm{p}<0.05)$ are bolded while italicized values depict a trend $(0.05<\mathrm{p}<0.10) .{ }^{1}$ denotes a $\log$ transformed variable.

\begin{tabular}{c|ccc}
\hline \multirow{4}{*}{ Growth } & Dependent Variable & All Treatments & $\begin{array}{c}\text { Garlic Mustard } \\
\text { Treatments }\end{array}$ \\
\cline { 2 - 4 } & Root Length $(\mathrm{cm})$ & $\mathbf{p}=\mathbf{0 . 0 0 1 5}$ & $\mathbf{p}=\mathbf{0 . 0 1 3 4}$ \\
Variables & Shoot Length $(\mathrm{cm})$ & $\mathbf{p}=\mathbf{0 . 0 1 4 6}$ & $\mathrm{p}=0.1476$ \\
& Shoot Mass $(\mathrm{g})$ & $\mathrm{p}=0.2399$ & $\mathrm{p}=0.7295$ \\
& Total Biomass $(\mathrm{g})^{1}$ & $\mathrm{p}=0.6139$ & $\mathrm{p}=0.8576$ \\
& Root: Shoot Ratio & $\mathrm{p}=0.1306$ & $\mathrm{p}=0.5064$ \\
& Leaf Area $\left(\mathrm{cm}^{2}\right)^{1}$ & $\mathrm{p}=0.0693$ & $\mathrm{p}=0.1663$ \\
\hline \multirow{3}{*}{ Reproductive } & \# offlower buds & $\mathbf{p}=\mathbf{0 . 0 0 4 4}$ & $\mathbf{p}=\mathbf{0 . 0 0 3 3}$ \\
Variables & \# of berries & $\mathrm{p}=0.7454$ & $\mathrm{p}=0.9137$ \\
& \# of seeds & $\mathrm{p}=0.7830$ & $\mathrm{p}=0.9853$ \\
& Reproductive Mass $(\mathrm{g})^{1}$ & $\mathbf{p}=\mathbf{0 . 0 0 6 4}$ & $\mathrm{p}=0.2191$ \\
\hline
\end{tabular}


Table 4.2: ANOVA summary table of block effects for growth variables and reproductive variables for the leaf litter addition study; significant values $(p<0.05)$ are bolded while italicized values depict a trend $(0.05<\mathrm{p}<0.10) .{ }^{1}$ denotes a $\log$ transformed variable.

\begin{tabular}{c|ccc}
\hline \multirow{4}{*}{ Growth } & Dependent Variable & All Treatments & $\begin{array}{c}\text { Garlic Mustard } \\
\text { Treatments }\end{array}$ \\
\cline { 2 - 4 } & Root Length $(\mathrm{cm})$ & $\mathrm{p}=0.2995$ & $\mathrm{p}=0.8877$ \\
Variables & Shoot Length $(\mathrm{cm})$ & $\mathrm{p}=0.8157$ & $\mathrm{p}=0.5202$ \\
& Root Mass $(\mathrm{g})^{l}$ & $\mathrm{p}=0.6374$ & $\mathrm{p}=0.9730$ \\
& Shoot Mass $(\mathrm{g})$ & $\mathbf{p}=\mathbf{0 . 0 0 0 7}$ & $p=0.0911$ \\
& Total Biomass $(\mathrm{g})$ & $\mathrm{p}=0.2405$ & $\mathrm{p}=0.9576$ \\
& Root:Shoot Ratio & $\mathbf{p}=\mathbf{0 . 0 0 0 2}$ & $\mathbf{p}=\mathbf{0 . 0 1 3 3}$ \\
& RGR $_{\text {RW }}$ & $\mathrm{p}=0.2951$ & $\mathrm{p}=0.2870$ \\
\hline \multirow{5}{*}{ Reproductive } & \# of flower buds & $\mathrm{p}=0.4105$ & $p=0.0861$ \\
Variables & \# of berries & $\mathbf{p}=\mathbf{0 . 0 3 2 9}$ & $\mathbf{p}=\mathbf{0 . 0 3 8 0}$ \\
& \# of seeds & $p=0.0559$ & $p=0.0524$ \\
& Berries/flower bud & $\mathbf{p}<\mathbf{0 . 0 0 0 1}$ & $\mathbf{p}=\mathbf{0 . 0 2 7 9}$ \\
& Seeds/flower bud & $\mathbf{p}<\mathbf{0 . 0 0 0 1}$ & $\mathbf{p}=\mathbf{0 . 0 1 8 3}$ \\
& Reproductive Mass $(\mathrm{g})^{1}$ & $\mathbf{p}<\mathbf{0 . 0 0 0 1}$ & $p=0.0531$ \\
\hline
\end{tabular}



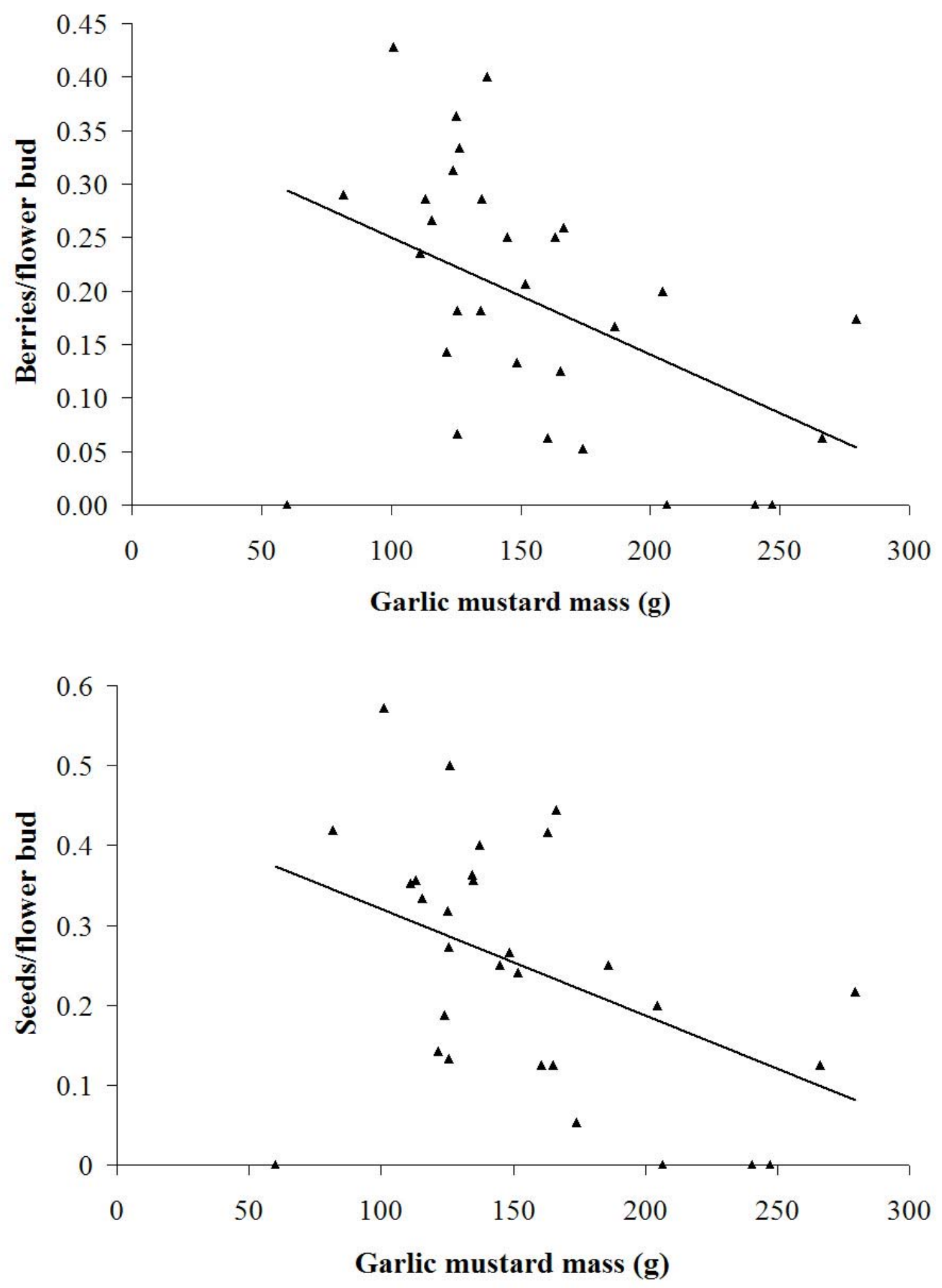

Figure 4.1: (a) One-way regression showing relationship between mean berries/flower bud for ginseng and initial mass of garlic mustard leaf litter and (b) relationship between mean seeds/flower bud 


\section{Effects of garlic mustard leaf litter addition}

In all treatments and within GM treatments, ginseng growth was not significantly affected by the presence of GM ( $\mathrm{p}>0.05)$. However, in all treatments, block had a significant effect on shoot mass and the root:shoot ratio (Table 4.2). Block also had a significant effect on the root:shoot ratio as well as a trend to effect shoot mass within GM treatments (Table 4.2).

In terms of reproductive characteristics, initial GM mass had no significant effect on the total number of buds, the number of berries, the number of seeds and the reproductive mass of ginseng plants ( $\mathrm{p}>0.05)$. However, initial GM mass had a tendency to decrease the proportion of flower buds that developed into berries $(\mathrm{F}=3.4333$, $p=0.0768$; Fig. 4.1a) and the number of seeds per bud $(F=3.0116, p=0.0961$; Fig. 4.1b). In all treatments, block had a significant effect on the number of berries, the proportion of flower buds that developed into berries, the number of seeds per bud as well as the reproductive mass (Table 4.2). In all treatments, block also had a tendency to affect the number of seeds (Table 4.2). Within GM treatments, there was a significant effect of block on the number of berries as well as the proportion of buds which became berries and seeds (Table 4.2). Within GM treatments, there was a trend for block to affect the number of buds, the number of seeds and the reproductive mass (Table 4.2).

\section{DISCUSSION}

Overall, garlic mustard density and leaf litter addition had no effect on ginseng growth variables. Adult ginseng plants have a thick taproot, and most of its growth in 2008 was very likely a function of growing conditions in the previous year. Our leaf litter addition study was an attempt to introduce fairly extreme garlic mustard effects; 
however, ginseng plants were unresponsive to this treatment. In a previous competition study by Meekins and McCarthy (1999), garlic mustard's competitive effects were found to be species-specific as chestnut oak (Quercus prinus) seedling biomass was $34.8 \%$ lower in competition with garlic mustard than in monoculture. In contrast, seedling biomass of spotted jewelweed (Impatiens capensis) and box elder (Acer negundo) were significantly higher in competition with garlic mustard than in monoculture (Meekins and McCarthy 1999). In addition, jack-in-the-pulpit (Arisaema triphyllim), sugar maple (Acer saccharum), red maple (Acer rubrum) and white ash (Fraxinus americana) grew significantly less in soils previously invaded by garlic mustard while wheat growth was significantly higher (Stinson et al. 2006; Rodgers et al. 2008). The results from previous garlic mustard studies in addition to our results indicate that native species' growth in garlic mustard invaded areas is variable.

Within the garlic mustard leaf litter addition treatments, two reproductive variables were negatively influenced as mass of garlic mustard increased. Plants tend to reduce reproductive investment, especially in times of stress (Grime 1979; Chiariello and Gulmon 1991; Sun et al. 2004). Ginseng naturally exhibits a low reproductive potential (Carpenter and Cottam 1982; Lewis and Zenger 1983; Charron and Gagnon 1991), and recruitment within a population is dependent on seed production. Therefore, the negative effect of garlic mustard on reproduction may have a large impact on fecundity of ginseng.

While the mechanism for reproductive suppression by garlic mustard leaf litter addition is not known, allelopathy may be a cause. Vaughn and Berhow (1999) found that glucosinolate concentrations in garlic mustard were highest in the fall following flowering, indicating that senescence may produce the highest concentrations of 
allelochemicals. Decomposition of Brassica spp. glucosinolates in soils also can breakdown into isothiocyanates which have pesticidal activities (Borek et al. 1994;

Brown et al. 1994; Shreiner and Koide 1993 a,b). It is possible that garlic mustard (also in Brassicaceae) has a similar isothiocyanate release which may suppress beneficial soil microbes such as mycorrhizal fungi.

Overall, while even extreme garlic mustard treatments had no effect on ginseng growth, there was a tendency for garlic mustard to suppress berry and seed production. This result could have negative implications for future ginseng recruitment in invaded populations. Furthermore, it is possible that garlic mustard effects may be cumulative over time as the invasive has the ability to alter the soil environment (Klinoromos 2002; Stinson et al. 2006; Callaway et al. 2008; Rodgers et al. 2008). 


\section{REFERENCES}

Antonovics J, Levin DA (1980) The ecological and genetic consequences of density dependent regulation in plants. Ann Rev Ecol Systematics 11: 411-452.

Bailey B (1999) Social and economic impacts of wild harvested products. Ph.D. Dissertation, West Virginia University, Morgantown, WV.

Baskin JM, Baskin CC (1992) Seed germination biology of the weedy biennial Alliaria petiolata. Nat Areas J 12:191-197.

Borek V, Morra MJ, Brown PD, McCaffrey JP (1994) Allelochemicals produced during sinigrin decomposition in the soil. J Agri Food Chem 42:10301034.

Brown PD, Morra MJ, Borek V (1994) Gas chromatography of allelochemicals produced during glucosinolate degradation in the soil. J Agri Food Chem 42: 2029-2034.

Byers DL, Quinn JA (1998) Demographic variation in Alliaria petiolata (Brassicaceae) in four contrasting habitats. J Torrey Bot Soc 125: 138-149.

Callaway RM, Cipollini D, Barto K, Thelen GC, Hallett SG, Prati D, Stinson K, Klironomos J (2008) Novel weapons: Invasive plant suppresses fungal mutualists in America but not in its native Europe. Ecology 89(4):1043-1055.

Carpenter SG, Cottam G (1982) Growth and reproduction of American ginseng (Panax quinquefolius) in Wisconsin, USA. Can J Bot 60: 2692-2696.

Cavers, PB, Heagy MI, Kokron RF (1979) The biology of Canadian weeds. 35. Alliaria petiolata (M. Bieb) Cavara and Grande. Can J Plant Science 59:217-229.

Charron D, Gagnon D (1991) The demography of northern populations of Panax quinquefolium (American ginseng). J Ecol 79(2):431-445.

Chiariello NR, Gulmon SL (1991) Stress effects on plant reproduction. In: Mooney HA, Winner WE, Pell EJ, Chu E (Eds.), Response of plants to multiple stresses. Academic Press, San Diego, USA, pp. 161-188.

Cipollini D, Gruner B (2007) Cyanide in the chemical arsenal of garlic mustard, Alliaria petiolata. J Chem Ecol 33:85-94.

Cruse-Sanders JM, Hamrick JL (2004) Spatial and genetic structure within populations of wild American ginseng (Panax quinquefolius L. Araliaceae). $\mathrm{J}$ of Hered 95(4):309-321. 
Ford ED (1975) Competition and stand structure in some even-aged monocultures. J Ecol 63:311-333

Grime J P (1979) Plant strategies and vegetation processes. John Wiley, New York, USA.

Klironomos JN (2002) Feedback with soil biota contributes to plant rarity and invasiveness in communities. Nature 417:67-70.

Lewis WH, Zenger VE (1983) Breeding systems and fecundity in ginseng, Panax quinquefolium (Aralicaceae). Am J Bot 70:466-468.

McGraw JB, Garbutt K (1990) Demographic growth analysis. Ecology 71(3): 11992004.

McGraw JB, Sanders SM, Van der Voort ME (2003) Distribution and abundance of Hydrastis canadensis L. (Ranunculaceae) and Panax quinquefolius L. (Araliaceae) in the central Appalachian region. J Torrey Bot Soc 130(2): 62-69.

McGraw JB, Furedi MA (2005) Deer browsing and population viability of a forest understory plant. Science 307:920-922.

Meekins JF, McCarthy BC (1999) Competitive ability of Alliaria petiolata (Garlic mustard, Brassicaceae), an invasive, nonindigenous forest herb. Internat J Plant Science 160(4):743-752.

Mooney EH, McGraw JB (2007) Alteration of selection regime resulting from harvest of American ginseng, Panax quinquefolius. Conserv Genet 8:57-67.

Nuzzo V (1993) Distribution and spread of the invasive biennial garlic mustard (Alliaria petiolata) in North America. In: McKnight BN (ed.) Biological pollution: the control and impact of invasive exotic species. Indiana Academy of Science, Indianapolis. pp 137-146.

Nuzzo VA (1999) Invasion pattern of herb garlic mustard (Alliaria petiolata) in high quality forests. Biol Invasions 1(2): 169-179.

Palmblad IG (1968) Competition in experimental populations of weeds with emphasis on the regulation of population size. Ecology 49:26-34.

Prati D, Bossdorf O (2004) Allelopathic inhibition of germination by Alliaria petiolata (Brassicaceae). Am J Bot 91(2):285-288.

Rasband, W.S. 2005. ImageJ; v1.37, U. S. National Institutes of Health, Bethesda, Maryland, USA, http://rsb.info.nih.gov/ij/. 
Robbins CS (2000) Comparative analysis of management regimes and medicinal plant trade monitoring mechanisms for American ginseng and goldenseal. Conserv Biol 1422-1434.

Rodgers VL, Wolfe BE,. Werden LK, Finzi AC (2008) The invasive species Alliaria petiolata (garlic mustard) increases soil nutrient availability in northern hardwood-conifer forests. Oecologia 157:459-471.

Schreiner RP, Koide RT (1993a) Antifungal compounds from the roots of mycotrophic and non-mycotrophic plant species. New Phytologist 123:99-105.

Schreiner RP, Koide RT (1993b). Mustards, mustard oils and mycorrhizas. New Phytologist 123:107-113.

Seo H, Anderson RC (1990) Effect of soil microbial and mycorrhizal associations on the productivity and photosynthetic rates of Panax quinquefolium L. Myco Soc Am Newsl 41:4.

Smith SE, Read DJ (1997) Mycorrhizal Symbiosis. 2nd ed. New York:Academic Press

Stinson KA, Campbell SA, Powell JR, Wolfe BE, Callaway RM, Thelen GC, Hallett SG, Prati D, Klironomos JN (2006) Invasive plant suppresses the growth of native tree seedlings by disrupting belowground mutualisms. PLoS Biol 4(5): 0727-0731.

Stinson K, Kaufman S, Durbin L, Lowenstein F (2007) Impacts of garlic mustard invasion on a forest understory community. Northeast Nat 14(10):73-88.

Sun K, Hunt K, Hauser BA (2004) Ovule abortion in Arabidopsis triggered by stress. Plant Phys 135(4): 2358- 2367.

Thomas SC, Weiner J (1989) Including competitive asymmetry in measures of local interference in plant populations. Oecologia 80(3): 349-355.

Trimbur TJ (1973) An ecological life history of Alliaria officinalis, a deciduous forest "weed." MS thesis. The Ohio State University, Columbus, Ohio.

Van der Voort ME, McGraw JB (2006) Effects of harvester behavior on population growth rate affects sustainability of ginseng trade. Biol Conserv 130(4): 505-516.

Vaughn SF, Berhow MA, (1999) Allelochemicals isolated from tissues of the invasive weed garlic mustard (Alliaria petiolata). J Chem Ecol 25(11):2495-2504. 
Weber JS, Gibson KD (2007) Exotic plant species in old-growth forest in Indiana. Weed Sci 55:299-304.

Weiner J (1990) Asymmetric competition in plant populations. Trends Ecol Evol 5: 360-364.

Wixted K, McGraw JB (2008) A Panax-centric view of invasive species. Biological Invasions doi: 10.1007/s10530-008-9301-7.

\section{ACKNOWLEDGEMENTS}

Funding for this project was provided by NSF grant DEB-0613611 to J. B. McGraw. We also would like to thank numerous people who contributed to this project, especially landowners, and those assisting with field work - Alyssa Hanna, David Kazyak, Jerry Baird and Zachary Bradford. 


\section{Chapter V}

GENERAL CONCLUSIONS 
Invasive species have been well documented as biologically damaging to the ecosystems they invade (Vitousek et al. 1987; Wilcove et al. 1998; Ehrenfeld and Scott 2001). Furthermore, native species' recruitment and diversity has been found to be reduced in invaded areas (McCarthy 1997; Thomson 2005; Stinson et al. 2007).

Documenting the presence of invasive plants within populations of native plants is one of the first steps to managing invasion. However, until my research, no one had examined the potential effects of invasive plant species on the economically valuable, native plant species, American ginseng (Panax quinquefolius L.).

The objectives of my second chapter were to assess the level of exposure of ginseng individuals and populations to invasive plant species and to examine what factors may predict the presence of invasives in ginseng populations. Using a novel approach of plant-centric sampling, I documented a high level of invasion among natural ginseng populations in the core of its range. This method was unique in that it allowed us to quantify what invasive plants were present in forest interiors from the point of view of a native plant. The diversity of habitats that ginseng occupies (McGraw et al. 2003) as well as its similar life history strategies to other forest understory herbs suggests that other native species may experience comparable levels of exposure. For example, some of the most common herbs within ginseng populations in Illinois included Smilacina racemosa, Arisaema triphyllum, Sanicula marilandica, Phryma leptostacha, Podophyllum peltatum, Circaea quadrisulcata, Sanguinaria canadensis, Galium circaezans, Geranium maculatum and Osmorhiza claytonia (Anderson et al. 1993). Factors such as past land-use history (Lundgren et al. 2004) and previous disturbance may explain the high level of invasion. Multiflora rose (Rosa multiflora) and Japanese 
barberry (Berberis thunbergii) were the most prevalent invasive species near individual ginseng and within populations. These species, in addition to bush honeysuckles (Lonicera spp.), are bird and mammal dispersed, which may explain their presence in forest interiors (Vellend 2002; Myers et al. 2004; Ehrenfeld 1997). Furthermore, larger populations of ginseng and those which had been previously harvested were more likely to contain invasive plants, two results which may be similar for other wild harvested species. The abundance of invasive plants within ginseng populations and near this important species implies that competitive interactions could have high economic and ecological costs.

Given the high level of invasion among ginseng populations and individuals, I then examined how the invasive garlic mustard (Alliaria petiolata) may affect ginseng survival, growth and reproduction. When examining the competitive and allelopathic effects of garlic mustard on ginseng seedlings, I found several significant results. Activated carbon, a tool for allelopathy research, had a significant positive effect on several ginseng growth variables, a finding similar to those reported by Lau et al. (2008). The results from my study, as well as Lau et al. (2008), suggest that more research is needed on how particular species may respond to carbon addition in soils as this factor may alter soil nutrients. In addition, ginseng mortality increased with the presence of a competitor; however, within garlic mustard treatments, there was a tendency for $20 \%$ greater mortality in the absence of carbon. This effect was not seen within the native striped violet treatments and was consistent with allelopathic effects. Therefore, garlic mustard may limit ginseng recruitment, an effect which could have consequences within invaded populations. In terms of growth, ginseng was not significantly affected by garlic 
mustard competition or allelopathy. Past studies have found that different species have different responses to garlic mustard competition (Meekins and McCarthy 1999; Prati and Bossdorf 2004; Stinson et al. 2006; Rodgers et al. 2008). In our study, ginseng seedlings were resilient to low levels of competition; however, seedling survival may be limited in invaded populations.

While ginseng at the seedling stage are most susceptible to mortality, I was also interested in how adult plants would be affected by garlic mustard. Therefore, the objectives of my fourth chapter were to investigate how density of garlic mustard and addition of leaf litter may affect ginseng survival, growth and reproduction. Within both studies, I found no significant effect of garlic mustard density or leaf litter addition on ginseng growth. These results were consistent with findings from my seedling study and show that established plants may be resistant to the negative effects of garlic mustard. However, within the leaf litter addition study, two ginseng reproductive variables tended to be negatively affected by increased garlic mustard weight. As the weight of garlic mustard leaf litter increased, the proportion of flower buds which developed into berries decreased as well as the number of seeds per bud. Many studies have found that in times of stress, plants tend to decrease reproductive investment (e.g. Grime 1979; Chiariello and Gulmon 1991; Sun et al. 2004) which may have been the case for ginseng plants in my study. The fact that seed production had a tendency to decline with increased garlic mustard could have negative implications for the fecundity of ginseng in densely invaded populations.

Invasion of wild ginseng populations by non-native plant species has many implications. Altogether, the objectives of these studies were to evaluate the level of 
invasion and potential effects of a particular invasive, garlic mustard, in order to address a facet of conservation and management concern for wild ginseng. The surprisingly high level of invasion among ginseng populations and near individuals prompts a need to understand interactions between these species and if they might affect ginseng as well as other understory herbs. While garlic mustard was my main focus, several other invasive species found within ginseng populations also may be problematic. For example, Japanese barberry (Berberis thunbergii) has been found to alter soil microbial community structure (Kourtev et al. 2002; Kourtev et al. 2003), and Japanese honeysuckle (Lonicera japonica) can form thick vegetative mats that exclude native seedlings (Hardt 1986; Myster and Pickett 1992). Furthermore, Amur honeysuckle (Lonicera maackii) and Tree-of-Heaven (Ailanthus altissima) have been found to exhibit allelopathic properties (Dorning and Cippollini 2005; Heisey 1990; Heisey 1996; De Feo et al. 2003).

Therefore, future research should focus on how other invasive species may affect survival and growth of ginseng as well as other understory species commonly found in ginseng habitat.

Several limitations also existed within my studies. My field studies occurred at only one site per study, and results from my fourth chapter indicated that microsite variation can affect several ginseng growth and reproductive variables. Therefore, it is possible that results found within my studies may have varied at different locations. Furthermore, in my third chapter, I collected garlic mustard seeds to prevent invasion at the site and harvested garlic mustard early to collect biomass data. However, studies have found high concentrations of phytotoxic chemicals within garlic mustard seeds (Larsen et al. 1983) and within the fall of its second year of growth (Vaughn and Berhow 
1999). Therefore, garlic mustard within my study may have not exerted its full allelopathic effect. For my fourth chapter, I also began the decomposition study in the spring, when garlic mustard would have been naturally growing. However, this was done to elicit the maximum effects of garlic mustard decomposition on ginseng plants.

Despite these limitations, the surprisingly high level of invasion among ginseng populations and near individuals prompts a need to understand interactions between these species and if they might affect ginseng as well as other understory herbs. My garlic mustard research also has shown a tendency for garlic mustard to increase seedling mortality and decrease reproductive effort in adult ginseng. These factors combined with the low reproductive potential of ginseng may ultimately influence future population growth within garlic mustard invaded areas. 


\section{REFERENCES}

Anderson RC, Fralish JS, Armstrong JE (1993) The ecology and biology of Panax quinquefolium L. (Araliaceae) in Illinois. Am Midl Nat 129:357-372.

Chiariello NR, Gulmon SL (1991) Stress effects on plant reproduction. In: Mooney HA, Winner WE, Pell EJ, Chu E (Eds.), Response of plants to multiple stresses. Academic Press, San Diego, USA, pp. 161-188.

De Feo V, De Martino L, Quaranta E, Pizza C (2003) Isolation of phytotoxic compounds from tree-of-heaven (Ailanthus altissima Swingle). J Agric Food Chem 51(5): $1177-1180$.

Dorning M, Cipollini D (2005) Leaf and root extracts of the invasive shrub, Lonicera maackii, inhibit seed germination of three herbs with no autotoxic effects. Plant Ecol 184(2):287-296.

Ehrenfeld JG (1997) Invasion of deciduous forest preserves in the New York metropolitan region by Japanese barberry (Berberis thunbergii DC). J Torrey Bot Soc 124(2): 210-215.

Ehrenfeld JG, Scott NS (2001) Invasive species and the soil: effects on organisms and ecosystem processes. Ecol Appl 11(5): 1259-1260.

Grime J P (1979) Plant strategies and vegetation processes. John Wiley, New York, USA.

Hardt RA (1986) Japanese honeysuckle: from "one of the best" to ruthless pest. Arnoldia 25(3): 27-34.

Heisey RM (1990) Allelopathic and herbicidal effects of extracts from Tree of Heaven (Ailanthus altissima). Am J of Bot 77(5): 662-670.

Heisey RM (1996) Identification of an allelopathic compound from Ailanthus altissima (Simaroubaceae) and characterization of its herbicidal activity. Am J Bot 83(2):192-200.

Kourtev PS, Ehrenfeld JG, Haggblom M (2002) Exotic plant species alter the microbial community structure and function in the soil. Ecology 83(11):3152-3166.

Kourtev PS, Ehrenfeld JG, Haggblom M (2003) Experimental analysis of the effect of exotic and native plant species on the structure and function of soil microbial communities. Soil Biol and Biochem 35:895-905.

Larsen LM, Olsen O, Plöger A, Sorenson H (1983) Sinapine-O- -Dglucopyranoside in seeds of Alliaria officinalis. Phytochemistry 22:219-222. 
Lau JA, Puliafico KP, Kopshever JA, Steltzer H, Jarvis EP, Schwarzländer M, Strauss SY, Hufbauer RA (2008) Inference of allelopathy is complicated by effects of activated carbon on plant growth. New Phytologist 178 (2):412-423.

Lundgren MR, Small CJ, Dreyer, GD (2004) Influence of land use and site characteristics on invasive plant abundance in the Quinebaug highlands of southern New England. Northeast Nat 11(3): 313-332

McCarthy B (1997) Response of a forest understory community to experimental removal of an invasive nonindigenous plant (Alliaria petiolata, Brassicaceae). In: Luken JO, Thieret JW (eds). Assessment and management of plant invasions. Springer-Verlag. New York. pp 117-130

McGraw JB, Sers SM, Van der Voort ME (2003) Distribution and abundance of Hydrastis canadensis L. (Ranunculaceae) and Panax quinquefolius L. (Araliaceae) in the central Appalachian region. J Torrey Bot Soc 130(2):62-69.

Meekins JF, McCarthy BC (1999) Competitive ability of Alliaria petiolata (Garlic mustard, Brassicaceae), an invasive, nonindigenous forest herb. Inter J Plant Sci 160(4):743-752.

Myers JA, Vellend M, Gardescu S, Marks PL (2004) Seed dispersal by white-tailed deer: implications for long-distance dispersal, invasion, and migration of plants in eastern North America. Oecologia 139(1):1432-1939.

Myster RW, Pickett STA (1992) Dynamics of associations between plants in ten old fields during 31 years of succession. J Ecol 80: 291-302.

Prati D, Bossdorf O (2004) Allelopathic inhibition of germination by Alliaria petiolata (Brassicaceae). Am J Bot 91(2):285-288.

Rodgers VL, Wolfe BE, Werden LK, Finzi AC (2008) The invasive species Alliaria petiolata (garlic mustard) increases soil nutrient availability in northern hardwood-conifer forests. Oecologia 157:459-471.

Stinson KA, Campbell SA, Powell JR, Wolfe BE, Callaway RM, Thelen GC, Hallett SG, Prati D, Klironomos JN (2006) Invasive plant suppresses the growth of native tree seedlings by disrupting belowground mutualisms. PLoS Biol 4(5): 0727-0731.

Stinson K, Kaufman S, Durbin L, Lowenstein F (2007) Impacts of garlic mustard invasion on a forest understory community. Northeastern Naturalist 14(10):73-88.

Sun K, Hunt K, Hauser BA (2004) Ovule abortion in Arabidopsis triggered by stress. Plant Phys 135(4): 2358- 2367. 
Thomson D (2005) Measuring the effects of invasive species on the demography of a rare endemic plant. Biol Invasions 7:615-624.

Vaughn SF, Berhow MA (1999) Allelochemicals isolated from tissues of the invasive weed garlic mustard (Alliaria petiolata). J Chem Ecol 25(11):2495-2504.

Vellend M (2002) A pest and an invader: white-tailed deer (Odocoileus virginianus Zimm.) as a seed dispersal agent for honeysuckle shrubs (Lonicera L.). Nat Area $\mathbf{J}$ 22(3):230-234.

Vitousek PM, Walker LR, Whiteaker LD, Mueller-Dombois D, Watson PA (1987). Biological invasion by Myrica faya alters ecosystem development in Hawaii. Science 238(4828): 802-804.

Wilcove DS, Rothstein D, Dubow J, Philips A, Losos E (1998) Quantifying threats to imperiled species in the United States. Bioscience 48(8):607-615. 


\section{KERRY LYNN WIXTED \\ CURRICULUM VitaE}

\section{HOME ADDRESS:}

1024 Arncliffe Rd

Baltimore, MD 21221

Phone: (301) 697-4026

Email: kwixted0@yahoo.com

\section{Academic Preparation:}

M.S.- Environmental and Evolutionary Biology

3.93 GPA

West Virginia University, Morgantown, WV, Jan. 2006- present

B.S.- Wildlife and Fisheries management major, Biology minor

3.66 GPA

Frostburg State University, Frostburg, MD, Sept. 2001-Dec. 2005

\section{Sample of courses taken:}

Environmental Chemical Analysis Wildlife Forensics Genetics

General Chemistry I \& II

Dendrology Mammalogy

Environmental Planning

Environmental Law

Plant Taxonomy

Applied GIS

Surface Water Hydrology

Biometry

\section{RESEARCH SKILLS:}

- Able to work $\mathrm{pH}$ meters, spectrophotometers, centrifuges, dissecting and light microscopes

- Able to conduct vegetative research

- Able to use fyke nets, bag seines, kick seines, backpack electroshockers, and parallel wires to sample fishes

- Able to mist net to capture birds

- Able to band and process owls

- Able to use Sherman live traps and mark small mammals

- Able to conduct water quality testing

- Familiar with plant, bird, mammal, and fish taxonomy and identification

- Proficient in Microsoft Word, Excel, PowerPoint, Photodraw, FrontPage

- Familiar with Adobe Photoshop 7.0; Macromedia Dreamweaver 2004; Ecological Methodology

- Designed and maintained web pages for FSU student chapter of The Wildlife society, FSU arboretum, WVU student chapter of the Wildlife Society, and the WVU Biology graduate student association 


\section{Professional EXPERIENCE:}

\section{Graduate Research Assistant/ Teaching Assistant}

Morgantown, WV (Spring 2006- Fall 2008)

- Designed and performed research on invasive plants and threats to American ginseng

- Performed demography census on ginseng populations as well as invasive plant species inventory

- Taught intro. biology and intro. physiology labs as well as capstone ecology research course to majors

- Taught environmental science lab to non-majors and graded for biometry class

- Took several classes concerning environmental GIS applications and techniques

\section{Laboratory Technician- Enviro-Chem Laboratories}

Baltimore, MD (December 2005)

- Tested total suspended solids (TSS), pH, turbidity, total phosphates (TP), and biochemical oxygen demand (BOD) on water samples

- Tested sedible solids (SS), percent solids (\% S), TCLP extractions, and on soil samples

- Cleaned labware and calibrated equipment

- Prepared samples to run on the AA, ICP, and IC

\section{Laboratory Technician- Appalachian Laboratory, U. of MD Center for Environ. Science}

Frostburg, MD (Fall 2003- Spring 2004; Spring 2005- Fall 2005)

- Performed water filtering, tested conductivity, acid-neutralizing capacity, and closed $\mathrm{pH}$

- Cleaned and acid-leached labware

- Collected water samples and performed field analysis using a portable hydro-lab

\section{Undergraduate Researcher- Ethnobotany Survey of Garrett County}

Frostburg, MD (Fall 2004-Fall 2005)

- Created and prepared mail survey under direction of Dr. Linda Lyon

- Conducted mail survey to determine level of medicinal plant knowledge in Garrett County, MD

\section{Summer Field Technician- West Virginia University}

Morgantown, WV (Summer 2005)

- Used backpack electroshocking units, parallel wires, bag seines, and fyke nets to sample fish

- Performed habitat analysis using 2004 EPA Wadable Streams Guide

- Helped identify, sort, measure, and record fish taxa

- Assisted with capture and collection of the Elk River population of the Crystal darter

\section{Volunteer- Northern Saw-Whet Owl Observational Study}

Oakland, MD (Fall 2004)

- Assisted in mist netting, banding, processing, and release of birds

\section{Volunteer- Hemlock and Birch Dominance Graduate Study}

Frostburg, MD (Fall 2004)

- Assisted with measuring nested plots and identification of tree species

- Helped take DBH measurements and tree core samples 
President- Frostburg State University student chapter of The Wildlife Society

Frostburg, MD (Fall 2004-present)

- Conducted meetings and coordinated guest speaker presentations, volunteer cleanups, Earth Day events, etc

- Attended and participated in 2002-2005 Southeastern Wildlife Conclaves

- Designed and maintained web page and email listserv to keep members informed

- Held position of secretary (Dec. 2002-Fall 2004)

\section{Tutor/ Counselor- Regional Math and Science Center}

Frostburg, MD (Summer 2002, 2003, 2004)

- Assisted class with science research projects pertaining to Ethnobotany, Biodiversity, and Acid Mine Drainage

- Chaperoned high school students on field trips and in a residential environment

- Planned and coordinated activities

\section{Americorps Volunteer- Frostburg State University Arboretum}

Frostburg, MD (Summer 2003-Spring 2004)

- Conducted an inventory of flora present in the arboretum

- Helped coordinate invasive plant removal work days

- Designed web page to summarize findings and to list information on tree species

Volunteer- Lateral Line Scale Analysis

Frostburg, MD (Spring 2003)

- Assisted with pulling, mounting, and measuring lateral line scales on fish

- Contributed data to Dr. Thomas Serfass's River Otter food habit project

\section{Tutor-Frostburg State University}

Frostburg, MD (Spring 2002- Spring 2003; Fall 2004)

- Tutored General Biology to undergraduate students

- Certified by the College Reading and Learning Association

\section{Employee- Sea Life Custom Aquarium Services}

Baltimore, MD (Summer 2001)

- Cleaned and serviced saltwater and freshwater aquariums

- Gained knowledge on various breeds of aquarium fish

\section{Intern- Aquaculture Research Center; U. of MD Biotechnology Institute}

Baltimore, MD (Fall 2000-Spring 2001)

- Conducted research on inorganic vs. organic nitrogen cycling rates

- Tested water quality, cleaned facility, and assisted with general maintenance

\section{Professional Memberships:}

- The Wildlife Society

- The Wildlife Society, MD/DE Chapter

- The Wildlife Society, President, Frostburg State University Chapter

- The Wildlife Society, Historian, West Virginia University Chapter

- Sierra Student Coalition, Frostburg State University Chapter

- Phi Eta Sigma Freshman Honors Society

- Biology Graduate Student Association, Historian, West Virginia University 


\section{HoNORS AND AWARDS:}

- Dean's List

2001-2004

- Frostburg State University Honors Program

2001- 2005

- Frostburg State University Academic Excellence Scholarship

2001-2005

- Hope Scholarship

2001-2005

- English Colloquium Invite

2003

- Undergraduate Research Opportunity, Honors program

2004-2005

- Nemacolin Chapter of Trout Unlimited Scholarship

2005

- Nominated to be Commencement Speaker 2005

- Departmental Honors, Biology 2005

- Teaching Assistantship

2006-2008

\section{Workshops/Professional Presentations}

Ecological Society of America (2008)

Poster: A Panax-centric view of Invasive Species

WVU Wildlife Society (2007)

Presentation: A Panax-centric view of invasive species and Allelopathic effects of garlic mustard

Regional Math and Science Center; Frostburg, MD (2007)

Presentation: If you can't beat 'em, eat 'em: A tasty way to combat invasive species

Frostburg State University (2006)

Presentation: How to get the most out of your undergraduate degree

Regional Math and Science Center; Frostburg, MD (2006)

Presentation: Invasion of the alien species

Frostburg City Council (2004)

Presentation (Group): Assessment of Piney Reservoir for non-motorized boat use

\section{Publications}

Wixted, K. and J.B. McGraw. A Panax-centric view of invasive species. Biological Invasions doi: 10.1007/s10530-008-9301-7. 